
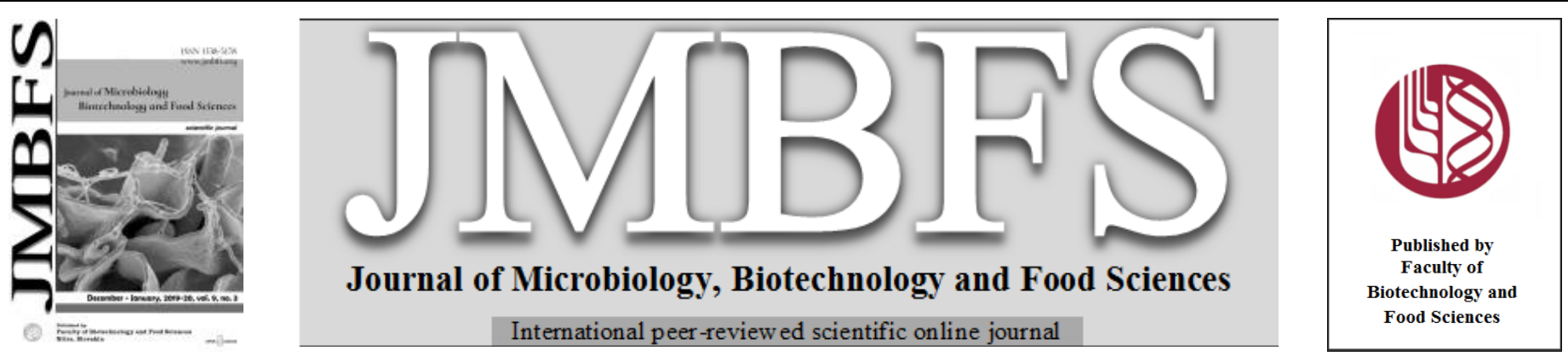

\title{
MASTITIS IN EWES: SOMATIC CELL COUNTS, PATHOGENS AND ANTIBIOTIC RESISTANCE
}

\author{
Kristína Tvarožková*1, Vladimír Tančin ${ }^{1,2}$, Ivan Holko $^{3}$, Michal Uhrinčat ${ }^{2}$, Lucia Mačuhová ${ }^{2}$ \\ Address(es): Ing. Kristína Tvarožková, \\ ${ }^{1}$ Department of Veterinary Sciences, Faculty of Agrobiology and Food Resources, Slovak University of Agriculture, Tr. A. Hlinku 2, 94976 Nitra, Slovak Republic. \\ ${ }^{2}$ NPPC-Research Institute for Animal Production Nitra, Hlohovecká 2, 95141 Lužianky, Slovak Republic. \\ ${ }^{3}$ VETSERVIS, s.r.o., Kalvária 3, 94901 Nitra.
}

*Corresponding author: kristina.tvarozkova@gmail.com

doi: 10.15414/jmbfs.2019/20.9.3.661-670

\section{ARTICLE INFO}

Received 7. 8. 2019

Revised 4. 9. 2019

Accepted 10. 9. 2019

Published 1. 12. 2019

Regular article

open $\partial_{\text {ACCESS }}$

\begin{abstract}
The aim of paper review is to describe the influence of somatic cell count (SCC) in the milk of ewes on the composition and milk production associated with the presence of mastitis pathogens as well as the assessment of the effects of non-infectious factors such as breed, number of lambs, order and stage of lactation, age, oestrus, livestock management, the impact of the month, the season to change the SCC in the milk of ewes. It also points to the possible physiological value of SCC in sheep milk for udder health assessment as it is generally accepted for dairy cows. The important part of this paper is to show antimicrobial resistance of mastitis pathogens. The more complex results obtained in Slovakia under experimental and practical conditions are discussed. In conclusion, taking into account all mentioned factors and studies, SCC could play important role in management of dairy ewes breeding to get acceptable milk performances and good udder health at comparable physiological levels as in dairy cows. Regular milk recording could significantly contribute to effort of farmers in mastitis control program.
\end{abstract}

Keywords: mastitis, somatic cell counts, pathogens, non-infectious factors, milk performance

\section{INTRODUCTION}

Sheep breeding has a rich tradition, history and indispensable position in the structure of animal production in Slovakia. Long-term research into milk production was performed in our conditions in the past (Masár, 1968; Mikuš, 1973; Margetín et al., 1995, 1996; Milerski et al., 2006). In recent years, the importance of research due to increasing demand of dairy for ewe's milk is increased. Thus these requirements force the animal practice to increase the milk production and its quality which reflect in the research aimed to study environmental influences and animal factors involved in milk production efficiency not only in our country (Oravcova et al., 2015; Mačuhová et al., 2017; Baranovič et al., 2018) but also in abroad this is key view (Gelasakis et al., 2015). Additionally, in 2017, a new breed of Slovak dairy sheep was approved by Ministry of agriculture and rural development of Slovak republic (based on the Improved Valachian, Tsigai as native breeds, Merino and dairy breeds of the Lacaune and East Friesian sheep milk to improve milk production) (detailed description in Margetín et al., 2017, review). Increasing milk production in dairy practice improves the economics of breeding, but on the other hand, puts increased demands on management of breeding, new approaches to milking, feeding, health etc.

To ensure the profitability of dairy sheep breeding the good health status of ewes, mammary gland especially, is very important. The health status of the mammary gland is considered to be one of the decisive factors influencing milk production and its nutritional, hygienic and technological quality (Gelasakis et al., 2015). The most frequent disease of mammary gland is mastitis with large negative economic impact on viability of farms and welfare of animals (Mork et al., 2007). Therefore, early diagnosis of the disease associated with effective treatment and further prevention of relapse, the emergence of new cases and the subsequent spread of mastitis in the herd is very necessary (Blagitz et al., 2014; Addis et al., 2016; Persson et al., 2017). An irreplaceable place in mastitis prevention has regular monitoring of the udder's health status (test day, in Slovakia only a few farms measure SCC) and the identification of the risks of breeding systems (milking setting, machine cleaning and milking routine deserve attention in our country) associated with the mentioned disease. Appropriate preventative measures and breeding systems are also based on the identification of the causes of the disease and the immune response of the affected individual. From 2016 a new project started (APVV-15-0072) to more complex analyse the health status of dairy ewes raised in Slovakia and to study or found out the cause of high somatic cell counts in relation to presence of microorganisms. The genetics, molecular and immune aspects are involved as well. As it was mentioned by Mork et al. (2007) differences in climate, production forms, and management practices may give rise to differences in epidemiology, bacteriology, and manifestations of mastitis. We would like to contribute to this world knowledge by more intensive research in our country.

The aim of the review is to summarize the knowledge and results of the health status of the mammary gland of ewes in the breeding conditions of Slovakian farming following by the research in this field in the world. The aim also includes prospects and activities for further research aimed at improving the health status of the mammary gland of dairy ewes.

\section{MASTITIS}

A serious health and economic problem in dairy ewes breeding is mastitis, which causes economic and breeding losses. Mastitis is inflammatory disease of mammary gland. Economical negative impact of mastitis in dairy sheep represent reduced milk production and its quality, increased cure costs (Riggio and Portolano, 2015). Mastitis contributes to increased costs of animal treatment, presence of pathogens and enterotoxins in milk which increases the risk for of human health (Pilipčincová et al., 2010). Intramammary infections are important also in meat production flocks, as reduced milk yield of ewes has been shown to lead to below-average growth of their lambs and higher mortality (Clements et al., 2003; Moroni et al., 2007; Gelasakis et al., 2015; Bramis et al., 2016). According to the form, this disease can be divided into clinical and subclinical mastitis (Bergonier and Berthelot, 2003; Mork et al., 2007; Bramis et al., 2016). Clinical mastitis is accompanied by symptoms such as swelling of the udder, fever, changes consistency and colour of milk, anorexia and significant decline in milk yield (Giadinis et al., 2012; Balabánová et al., 2014; Olechnowicz and Jaskowski, 2014). Clinical mastitis can lead to mortality or culling of up to $90 \%$ of mastitic ewes in the herd (Olechnowicz and Jaskowski, 2014). It is reported that the incidence of clinical mastitis in the ewes is lower than 5\% but the occurrence of subclinical mastitis is much higher (Bergonier and Berthelot, 2003; Moroni $\boldsymbol{e t}$ al., 2007; Kern et al., 2013; Olechnowicz and Jaskowski, 2014). 
The subclinical mastitis isn't accompanied by symptoms and visual changes in milk. For diagnose of subclinical mastitis can be used SCC. The most critical level of SCC considered as possible subclinical mastitis occurrence is SCC over $1000 \times$ $10^{3}$ cells/ml (Berthelot et al., 2006). Our preliminary results obtained in breeding practice based on SCC indicate that the incidence of subclinical mastitis according above mentioned threshold was $8.73 \%$ with the high variability among the farms (from 2 to $40 \%$ ) though the highest SCC was found out in farm with Lacaune breed (Tančin et al., 2017a). In another our study with Lacaune breed, only the percentage of subclinical mastitis was higher $19.21 \%$ with also high influence of farm (from 8 to 34\%) (Tančin et al., 2017b). Zigo et al. (2017) found out 5.9\% incidence of subclinical mastitis in their research farms in eastern Slovakia. Thus under these results the breed could play role in the occurrence of subclinica mastitis but the most important factor is management of the farm. From the abroad study, the conclusion could be similar because of the prevalence of subclinica mastitis is variable and ranges from less than 9 to $50 \%$ (Albenzio et al., 2002; McDougall et al., 2002; Hall and Rycroft, 2007; Olechnowicz and Jaskowski, 2014; Gelasakis et al., 2015). Moroni et al. (2007) found out that the incidence of subclinical intramammary infection was $51.2 \%$ in Bergamasca meat sheep. The prevalence of subclinical mastitis in ewes varied from $7.5 \%$ to $39 \%$ (Rahman $\boldsymbol{e}$ al., 2016) and in another study subclinical mastitis was detected in $26 \%$ of ewes (Vasileiou et al., 2018a). According Bergonier et al. (2003) and Contreras et al. (2007) the prevalence of subclinical mastitis ranged from 5 to $30 \%$.

\section{THE MOST COMMON MASTITIS PATHOGENS}

Intramammary infection is generally caused by microbial agent attack, mainly by bacteria, viruses, fungi and algae (Spuria et al., 2017). According to the origin of the organisms the mastitis could divided into contagious and environmental mastitis (Quinn et al., 2011). Thus the mastitis pathogens could be classified as contagious (Staphylococcus (S.) aureus, Streptococcus (Str.) agalactiae and Mycoplasma sp.) and environmental pathogens (Escherichia coli (E.), Mannheimia (M.) haemolytica, Pseudomonas aeruginosa, Streptococcus uberis, Enterococcus faecalis and coagulase-negative staphylococci (CNS)) (Albenzio et al., 2002; Contreras and Rodriguez 2011). According Quinn et al. (2011) CNS can be classified as minor contagious pathogens because are considered to be part of the normal flora of animals and S. aureus, Str. agalactiae and Mycoplasma sp. are classified as major contagious pathogens.

The most frequent pathogens isolated from the milk samples were CNS as well documented by many researchers (Moroni and Cuccuru, 2001; Boettcher et al., 2005; Guaraná et al., 2011; Santana et al., 2013; Zafalon et al., 2018). The etiological agents with highest occurrence in milk samples of ewes were CNS (Zafalon et al., 2016). Zafalon et al. (2016) found out the incidence of CNS in $56.8 \%$ of bacteriology positive samples. CNS were detected in $59.7 \%$ of cases of subclinical mastitis in study of Vasileiou et al. (2018a). The most common CNS that cause intramammary subclinical infection of sheep and goats is $S$. epidermidis (Leitner et al., 2004b; Moroni et al., 2005a, 2005b; Pilipčincová et al., 2010; Kunz et al., 2011; Queiroga et al., 2018;) followed by S. chromogenes, S simulans, S. xylosus, S. caprae (Bergonier et al., 2003; Queiroga, 2017). In another study also CNS represented $44.9 \%$ of infected milk samples where $S$ epidermidis was again the most frequently isolated species, followed by $S$. xylosus and $S$. simulans (Moroni et al., 2007). In Brazil conditions the most of the analysed samples were bacteriologically negative (76\%), and among the positive samples, most of the isolates (93\%) were Staphylococcus sp., followed by Streptococcus $\mathrm{sp}$ (5\%) (Blagitz et al., 2014). According Rahman et al. (2016) CNS formed $88.80 \%$ isolates of Staphylococcus sp. CNS were the most prevalent pathogens (58\%) in milk samples with intramammary infection (Person et al., 2017). Zigo et al. (2014) in their study reported that CNS were identified in $65.4 \%$ of all positive isolates. As compared with above mentioned results Vasileiou et al. (2018a) identified $S$ chromogenes $(23.1 \%)$ as the most prevalent CNS followed by S. epidermidis $(19.8 \%)$ a $S$. simulans $(17.6 \%)$ in cases of subclinical mastitis.

Under Slovak dairy practice Pilipčincová et al. (2010) investigated the frequency of individual species of CNS in farms of eastern Slovakia and found occurrence of S. epidermidis $(36.3 \%)$, S. caprae $(21.3 \%)$, S. hominis $(6.6 \%)$, S. chromogenes $(6.3 \%)$, S. xylosus $(5.8 \%)$, S. warneri $(5.0 \%)$, S. capitis $(4.6 \%)$. Also in another study in Slovakia the most frequent pathogens in milk samples from ewes were CNS S. epidermidis (16.0\%), S. chromogenes (11.9\%), S. simulans (7.0\%), S schleiferi (6.4\%) (Zigo et al., 2014). However, in other study Zigo et al. (2011) from 204 individual positive samples identified S. schleiferi $(43.1 \%)$, S. caprae (16.2\%), S. chromogenes (10.3\%), S. epidermidis (8.3\%). Recently Zigo et al. (2017) reported that $S$. chromogenes $(14.3 \%$ ) was the most frequent CNS, followed by $S$. schleiferi $(12.2 \%)$ and S. epidermidis $(10.2 \%)$ in farms of eastern Slovakia. In milk samples positive on Staphylococcus sp. were the most frequent $S$ epidermidis (24.3\%), S. schleiferi $(16.6 \%)$ and S. chromogenes $(15.3 \%)$ (Vasil' et al., 2018). In our previous partial results of the study carried out in Slovakia (116 half udder samples), the most prevalent pathogens were CNS represented by $S$ chromogenes $(33.33 \%)$, S. xylosus $(21.67 \%)$, S. epidermidis $(5 \%)$ (Tančin et al., 2017c). Holko et al. (2018) found out that CNS were the most represented species in ewes milk.
S. aureus starts to be emerging problems for public health especially antibiotic resistant strains as pointed out in review of Gelasakis et al. (2015). S. aureus is the most frequent pathogen causing clinical mastitis in dairy ewes (Ariznabarreta et al., 2002; Bergonier et al., 2003; Mavrogianni et al., 2011; Dore et al., 2016) with around $40 \%$ of cases of clinical mastitis in suckling ewes and $80 \%$ of cases in dairy ewes (Mørk et al., 2007; Koop et al., 2010; Mavrogianni et al., 2011). S aureus was isolated in $8.36 \%$ of infected milk samples in meat sheep (Moroni $\boldsymbol{e}$ al., 2007). Ergún et al. (2009) showed 3.1\% incidence of $S$. aureus in samples without clinical sings. Kern et al. (2013) detected $S$. aureus in $5.5 \%$ of isolated bacteria. S. aureus was identified in $8.1 \%$ of bacteriology positive milk samples (Zafalon et al., 2016). The occurrence S. aureus was $9 \%$ in samples where intramammary infection was identified (Person et al., 2017). Vasileiou et al. (2018a) in their study determined $S$. aureus in $10.1 \%$ of cases of subclinical mastitis. Under our practical conditions $S$. aureus was identified in $9.3 \%(6.4 \%$ in clinical cases) from 204 individual positive samples (Zigo et al., 2011). In another study Zigo et al. (2014) determined the presence of S. aureus in $8.3 \%$ of individual milk samples. Vasil' et al. (2018) found out that S. aureus was isolated in $26.4 \%$ samples positive on Staphylococcus sp. during their research on farms of eastern Slovakia. From our study in dairy practice we found out $3.33 \%$ presence of $S$ aureus only (subclinical cases) (116 milk samples from half udders - 56 animals) (Tančin et al., 2017c). In another study in our conditions Holko et al. (2018) detected the incidence of $S$. aureus in $6.9 \%$ of microbial isolates.

Other pathogens causing sheep mastitis included Streptococcus sp. Increase in the occurrence of mastitis caused by bacteria Streptococcus sp. is usually caused by inappropriate hygiene of milking and housing (Marogna et al., 2010; Dore et al., 2016). Intramammary infection caused by Str. agalactiae is connected with high SCC (Ariznabarreta et al., 2002). Moroni et al. (2007) found out that Streptococcus sp. were the second most frequent pathogens of infected milk samples. In another study Streptococcus sp. were also the second most prevalent pathogen group isolated from milk samples of ewes, the most frequent was Str. uberis $(6.1 \%)$ followed by Str. dysgalactiae (2\%) and Str. agalactiae (2\%) which was isolated only from 1 flock (Ergün et al., 2009). From positive milk samples Marogna et al. (2010) isolated the most frequently 3 pathogens, Str. uberis, followed by $S$. epidermidis and $S$. aureus. Zafalon et al. (2016) detected Streptococcus sp. in $11 \%$ of cases with subclinical mastitis. Streptococcus sp. were determined in $4.7 \%$ of positive bacteriology milk samples (Vasileiou $\boldsymbol{e t}$ al., 2018a). Tančin et al. (2017c) observed in their studies $23.3 \%$ occurrence of Str. agalactiae, but Str. uberis, Str. parauberis, Enterococcus faecalis only in $1.67 \%$ samples for each pathogen. In another study in Slovak dairy practice were detected the occurrence of Str. agalactiae in 10.7\%, Str. dysgalactiae in $4.6 \%$ and Enterococcus faecium in $1.5 \%$ of positive isolates (Holko et al., 2018).

$M$. haemolytica cause intramammary infection in meat producing herds (Omaleki et al., 2010; Mavrogianni et al., 2011; Gelasakis et al., 2015). Only $11 \%$ of cases of intramammary infections caused by $M$. haemolytica were found in milk of dairy breeds (Mavrogianni et al., 2007). Persson et al. (2017) found out that the occurrence of $M$. haemolytica was in $6 \%$ of subclinical mastitis cases. The incidence of $M$. haemolytica was detected in $2.5 \%$ of cases of subclinical mastitis in ewes (Vasileiou et al., 2018a).

Intramammary infection can be also caused by Bacillus sp., Clostridium sp. Corynebacterium sp., Enterococcus sp., Listeria monocytogenes, Micrococcus sp. Mycobacterium sp. a Trueperella pyogenes (Ariznabarreta et al., 2002; Marogna et al., 2010). Moroni et al. (2007) detected Bacillus sp. in $14.3 \%$ of infected samples. Bacillus sp., Micrococcus sp. and Corynebacterium sp. were identified in 2\%, 2\% and 1\% isolated pathogens in Awassi breed, resp. (Ergün et al., 2009). Zafalon et al. (2016) showed $3.4 \%$ of cases with subclinical mastitis were caused by Micrococcus sp. Vasileiou et al. (2018a) found out that the occurrence of Corynebacterium sp., Micrococcus sp., Trueperella pyogenes, Bacillus sp. and Enterococcus sp. were 3.6\%, 2.6\%, 2.5\%, 1.6\%, $1.2 \%$, respectively.

Citrobacter sp., E. coli, Enterobacter sp., Klebsiella sp., Pasteurella multoocida, Proteus sp., Pseudomonas aeruginosa, Salmonella sp., Serretia sp., Yersinia pseudotuberculosis are environmental mastitis pathogens causing mastitis (Contreras and Rodríguez, 2011). These pathogens presented $3 \%$ isolated pathogens from milk samples in ewes (Bergonier et al., 2003). Ergün et al. (2009) determined Pseudomonas sp. in 2\% and E. coli in 2\% isolated pathogens in Awassi breed. E. coli was detected in $5.5 \%$ of isolated pathogens from milk samples in study of Kern et al. (2013). Vasileiou et al. (2018a) found out that the incidence of $E$. coli was determined in $3.4 \%$ of milk samples with subclinical mastitis. Zigo et al. (2017) determited $E$. coli in $1.2 \%$ from all testing samples. In our conditions was detected the occurrence of Klebsiella sp. below 1\% (Holko et al., 2018).

\section{ANTIMICROBIAL RESISTANCE}

The antimicrobial resistance is one of the most important challenge in the mastitis treatment. Therefore, research in this topic deserve high priority. Of 1284 strains $S$. aureus from ovine mastitis cases were evaluated for antibiotic susceptibility and were found increased resistance to streptomycin (48-87\%) and lower resistance were found to penicillin and ampicillin (2-12\% and $0-12 \%$, respectively) (Lollai et al., 2008). Attili et al. (2016) determined resistance $S$. aureus to enrofloxacin 
$(2.5 \mathrm{mg} / \mathrm{kg}$ and $5 \mathrm{mg} / \mathrm{kg})$. They found out that both treatments were effective, but treated with $5 \mathrm{mg} / \mathrm{kg}$ enrofloxacin was more effective for reduction clinical mastitis caused by $S$. aureus. The highest value of resistance of $S$. aureus were found on novobiocin $14.5 \%$, erythromycin $12.8 \%$, lincomycin $7.69 \%$ and penicillin $7.69 \%$ (Vasil' et al., 2018)

CNS were tested on susceptibility to antibiotics with rifampicin $(5 \mu \mathrm{g})$, linezolid $(30 \mu \mathrm{g})$, vancomycin $(30 \mu \mathrm{g})$, clindamycin $(2 \mu \mathrm{g})$, erythromycin $(15 \mu \mathrm{g})$, penicillin (10 IU), tetracycline $(30 \mu \mathrm{g})$, gentamicin $(10 \mu \mathrm{g})$, ciprofloxacin $(5 \mu \mathrm{g})$ and cotrimoxazole $(25 \mu \mathrm{g})$. Antibiotics were effective, but higher resistance were found for penicillin (17\%) and tetracycline (10.7\%) (Martins et al., 2017). Vasil' et al. (2018) detected susceptibility of S. epidermidis on 14 antibiotics, resistance was found in $11.1 \%$ to novobiocin and $8.3 \%$ to erythromycin. Holko et al. (2019) observed the highest resistance of CNS to lincomycin (57.65\%) and neomycin $(36.4 \%)$ and the lowest resistance to trimethoprim-sulfamethoxazole $(0 \%)$ and enrofloxacin $(3.0 \%)$. From our preliminary study in farm with Lacaune breed there were tested CNS susceptibility to following antibiotics: amoxicillin-clavulanic acid (AMC) $(20 \mu \mathrm{g}-10 \mu \mathrm{g})$, tetracycline (TE) $(30 \mu \mathrm{g})$, enrofloxacin (ENR) $(5 \mu \mathrm{g})$ trimethoprim-sulfamethoxazole (SXT) $(1.25 \mu \mathrm{g}-23.5 \mu \mathrm{g})$, neomycin $(\mathrm{N})(30 \mu \mathrm{g})$ lincomycin (MY) $(2 \mu \mathrm{g})$. We found out that the most effective antibiotics were amoxicillin-clavulanic acid and trimethoprim-sulfamethoxazole (tab.1) (Tvarožková et al., unpublished)

Table 1 Antimicrobial resistance of CNS (73 isolates) isolated from Lacaune ewe (Tvarožková et al., unpublished)

\begin{tabular}{lllllll} 
& AMC & TE & MY & ENR & SXT & N \\
\hline Susceptible & $90.91 \%$ & $78.79 \%$ & $54.55 \%$ & $84.85 \%$ & $90.91 \%$ & $36.36 \%$ \\
Intermediate & $3.03 \%$ & $3.03 \%$ & $9.09 \%$ & $12.12 \%$ & $6.06 \%$ & $45.45 \%$ \\
Resistant & $6.06 \%$ & $18.18 \%$ & $36.36 \%$ & $3.03 \%$ & $3.03 \%$ & $18.18 \%$
\end{tabular}

AMC- amoxicillin-clavulanic acid, TE- tetracycline, MY- lincomycin, ENRenrofloxacin, SXT- trimethoprim-sulfamethoxazole, $\mathrm{N}$ - neomycin.

Ergün et al. (2009) evaluated antimicrobial susceptibility of 78 Staphylococcus sp. isolates. They found out resistance on tetracycline $(24.4 \%)$, ampicillin $(42.3 \%)$, penicillin $(56.4 \%)$ and the most effective antibiotics were cephalothin $(97.4 \%)$, trimethoprim - sulphamethoxazol $(97.4 \%)$, amoxicillin-clavulanic acid $(97.4 \%)$, enrofloxacin $(94.9 \%)$, gentamycin $(92.3 \%)$, and erythromycin (84.6\%). Ünal et al. (2012) tested $46 \mathrm{CNS}$ and $21 \mathrm{~S}$. aureus isolates against antimicrobial agents. All Staphylococcus sp. were sensitive to cephalothin, trimethoprim-sulphamethoxazole, rifampin, cefoxitin, vancomycin and linezolide. $21 \mathrm{~S}$. aureus and $46 \mathrm{CNS}$ strains were resistant to penicillin G $19.0 \%$ and $30.4 \%$, to tetracycline $4.8 \%$ and $8.7 \%$, to erythromycin $4.8 \%$ and $6.5 \%$, to gentamicin $4.8 \%$ and $0.5 \%$, to enrofloxacin $0.0 \%$ and $0.5 \%$, respectively (Ünal et al., 2012). Rahman et al. (2016) found out that $85.18 \%$ of isolates were resistant to penicillin, to ampicillin were resistant $48.14 \%$ of isolates. The lowest resistance of drugs was observed in chloramphenicol, ciprofloxacin, neomycin and streptomycin (Rahman et al., 2016). Vasil' et al. (2016) determined the highest value of resistance to penicillin $(21.0 \%)$ neomycin $(10.5 \%)$ and novobiocin $(9.7 \%)$ The lowest values of resistance were found to cefoxitin $(0.8 \%)$, lincomycin $(2.4 \%)$, erythromycin and streptomycin (in both $3.2 \%$ ). Zigo et al. (2017) determined medium value of antibiotic resistance to penicillin $(11.7 \%)$, cloxacillin $(11.7 \%)$, ampicillin $(10.7 \%)$ and oxacillin $(10.7 \%)$. Other studies have nevertheless grouped staphylococcal strains independently of coagulase-production type and detected increased resistance to penicillin $\mathrm{G}$ (up to $31 \%$ ) and ampicillin (up to 30\%) (Corrente et al., 2003; Onni et al., 2011)

\section{DISCUSSED LIMITS FOR THE PHYSIOLOGICAL LEVEL OF THE SOMATIC CELL COUNTS}

Somatic cells in milk represent epithelial cells of alveoli and ducts and leukocytes (Paschino et al., 2019). SCC is considered from many aspects as an indicator of udder health and generally is used for detection of subclinical mastitis in ewes (Gonzalo et al., 1994; Gonzáles-Rodríguez et al., 1995; Margetín et al., 1996; Pengov, 2001; Olechnowicz et al., 2005). However, there is still a big discussion among scientists about the physiological level of SCC in udder of ewes for detection of udder health (Persson et al., 2017). From the research study of excellent laboratories in the world the discussed and proposed recommendations for physiological level of SCC in milk are systematically decreased during the last years.

Already in the 90 's it was considered at the physiological and pathophysiological level that the SCC limit ranged from 250 to $1000 \times 10^{3}$ cells $/ \mathrm{ml}$ (Gonzalo and Gaudioso Lacasa, 1985), and the authors proposed SCC at level $500 \times 10^{3} \mathrm{cells} / \mathrm{ml}$ for healthy udders. In the work of Hariharan et al. (2004) the limit for high SCC as a possible detection of mastitis was over $1000 \times 10^{3}$ cells $/ \mathrm{ml}$. Pengov (2001) determined physiological level of SCC in ewe's milk at $250 \times 10^{3}$ cells $/ \mathrm{ml}$. Values of SCC less than $500 \times 10^{3}$ cells $/ \mathrm{ml}$ for healthy ewes and for infected ewes SCC more than $1000 \times 10^{3}$ cells $/ \mathrm{ml}$ were reported by Berthelot $\boldsymbol{e t}$ al. (2006) and if SCC was in flock over $650 \times 10^{3}$ cells $/ \mathrm{ml}$ it showed $15 \%$ incidence of subclinical mastitis. Ewes with mammary glands without clinical abnormalities, with bacteriologically positive milk and with a SCC of $\geq 500 \times 10^{3}$ cells $/ \mathrm{ml}$, were considered to have subclinical mastitis (Kiossis et al., 2007). Maurer and Schaeren (2007) derived a critical limit at level $500 \times 10^{3}$ cells $/ \mathrm{ml}$ as indicator of problems with udder health. Leitner et al. (2008) established a limit for uninfected milk samples at $250 \times 10^{3}$ cells $/ \mathrm{ml}$ for Latxa sheep and for other sheep breeds. Nunes et al. (2008) followed Santa Inês sheep throughout lactation and reported that ideal value SCC for the diagnosis of mastitis was $500 \times 10^{3}$ cells $/ \mathrm{ml}$. Ozenc $\boldsymbol{e}$ al. (2011) specified a value for detection of subclinical mastitis at $374 \times 10^{3}$ cells/ml for Pirlak sheep. As a limit value in determining the relationship to milk yield Arias et al. (2012) determined $300 \times 10^{3}$ cells $/ \mathrm{ml}$. Kern et al. (2013) indicated threshold of SCC at $400 \times 10^{3}$ cells $/ \mathrm{ml}$ in meat breeds of sheep, $300 \times$ $10^{3}$ cells $/ \mathrm{ml}$ in dairy breeds and $100 \times 10^{3}$ cells $/ \mathrm{ml}$ in extensive breeds as right value in detecting problems with udder health. Limit for detection subclinical mastitis was determined by Hussein et al. (2015) as value of SCC $\geq 400 \times 10^{3}$ cells/ml in Ossimi sheep. Swiderek et al. (2016) determined as the limit for detection of subclinical mastitis SCC per $200 \times 10^{3}$ cells $/ \mathrm{ml}$. The value of SCC > $400 \times 10^{3}$ cells $/ \mathrm{ml}$ can be used for diagnostic of subclinical mastitis in flocks in Slohakieapredominant infectious aetiology is CNS (Zafalon et al., 2016). Caboni et al. (2017) reported similar threshold of SCC for diagnosis of mastitis in Sarda sheep, and in their study was determined the threshold of SCC at $265 \times 10^{3}$ cells $/ \mathrm{ml}$ In a study with meat and pelt producing ewes the possible limit for SCC as the health of udder indicator Persson et al. (2017) proposed less than $400-500 \times 10^{3}$ cells $/ \mathrm{ml}$. Sutera et al. (2018) in their study showed value SCC below $500 \times 10^{3}$ cells $/ \mathrm{ml}$ as a possible limit in relation to milk quality. The value of SCC $545 \times 10^{3}$ cells/ml can be proposed as limit of SCC for quality milk and cheese yield (Paschino et al., 2019). From above mentioned results it is clear that research deals very intensively to prove and establish the physiological level of SCC in milk for detection of mastitis as it is well accepted in dairy cows.

In our conditions Margetín et al. (2013) determined in breeding practise that only $6.3 \%$ milk samples had SCC over $1000 \times 10^{3}$ cells $/ \mathrm{ml}$. In the study of Idriss $\boldsymbol{e t}$ al. (2015) there was reported that $78 \%$ of the samples were below $600 \times 10^{3}$ cells $/ \mathrm{ml}$. In group of samples below $100 \times 10^{3}$ cells $/ \mathrm{ml}$ there were the highest percentage of sheep Tsigai breed and Improved Valachian as compared with Lacaune pure or crossbreed. Similarly, Vršková et al. (2015a) found out that $76 \%$ of Tsigai had SCC below $300 \times 10^{3}$ cells $/ \mathrm{ml}$. Tančin et al. (2017a) in their research detected that $82.03 \%$ individual milk samples were below $400 \times 10^{3}$ cells $/ \mathrm{ml}, 71.79 \%$ milk samples were below $200 \times 10^{3}$ cells $/ \mathrm{ml}$ and only $8.89 \%$ milk samples were over $1000 \times 10^{3}$ cells $/ \mathrm{ml}$. In other research Tančin $\boldsymbol{e t}$ al. $\mathbf{( 2 0 1 7 b )}$ determined that $53.36 \%$ milk samples were below $200 \times 10^{3}$ cells $/ \mathrm{ml}$ in Lacaune breed indicating a good udder health in high producing breed too. Baranovič et al. (2018) found out that in SCC group below $400 \times 10^{3}$ cells $/ \mathrm{ml}$ were $67.7 \%$ ewes in May and even $87.9 \%$ in July. In another study $60 \%$ of samples had SCC less than or equal to 200 $\times 10^{3}$ cells $/ \mathrm{ml}$ (Oravcová et al., 2018). Tvarožková et al. (2018) observed the most occurrence of ewes in SCC groups below $400 \times 10^{3}$ cells $/ \mathrm{ml}(78.89 \%$ in 2016 and $83.33 \%$ in 2017). Though above mentioned work significantly documented low physiological value for SCC level in ewe's milk, but in recently published article the limits for SCC were again much higher (Sutera et al., 2018). Thus the results of the scientific studies emphasise the need to specify the physiological values of SCC in raw sheep's milk in relation to the reliable detection of mastitis in ewes.

The importance of monitoring SCC in sheep milk showed Spanu et al. (2011) who found out that in ewes that were 3 or more months during lactation in SCC group above $400 \times 10^{3}$ cells $/ \mathrm{ml}$ were 5.6 to 7.5 -fold higher probability of a microbiologically positive samples compared to samples of milk from the ewes, which were below $400 \times 10^{3}$ cells $/ \mathrm{ml}$. Similarly, Ozenc et al. (2011) found out significantly higher SCC in contaminated samples as compared with uncontaminated ones. In our preliminary study we have also found out significantly higher SCC values in contaminated samples $(\log 5.28 \pm 0.09$ cells $/ \mathrm{ml})$ compared to uncontaminated ( $\log 4.73 \pm 0.06 \mathrm{cells} / \mathrm{ml}, \mathrm{P}<0.001)$ (Tančin et al., 2017c). Similarly, Bagnicka et al. (2011) also confirmed that SCC was higher in contaminated goat milk. A significant correlation between bacteriologically positive milk samples and CMT and SCC was found in another study (Blagitz et al., 2014). In our last mentioned study in SCC category below $400 \times 10^{3}$ cells $/ \mathrm{ml}$ were only $16.67 \%$ of contaminated samples (Tančin et al., 2017c). On the other hand, Hariharan et al. (2004) did not found out the differences in SCC between contaminated and free of pathogen ewes milk. In study with Pirlak ewes $13.2 \%$ contaminated samples had SCC below 500 $\times 10^{3}$ cells $/ \mathrm{ml}$ SCC and $25 \%$ uncontaminated samples had over last mentioned limit. As conclusion of above mentioned works the positive relationship between SCC in milk and presence of pathogens was not so clear. 


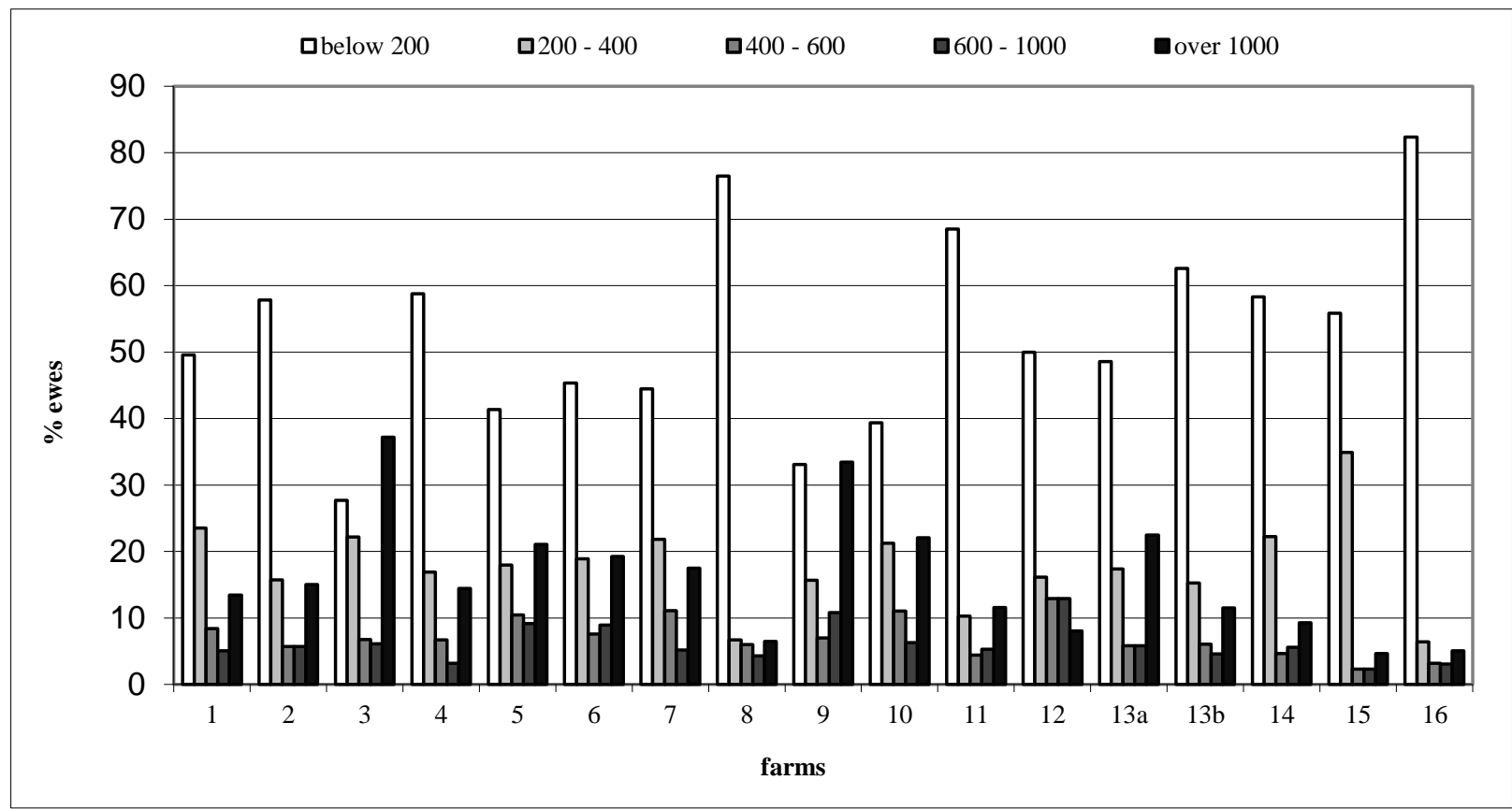

Figure 1 Frequency of occurrence ewes in five SCC groups $\left(\times 10^{3}\right.$ cells $\left./ \mathrm{ml}\right)$ in year 2016 (Baranovič et al., 2017)

Farms: 1, 2, 3, 4, 5, 6, 7, 8- Tsigai, 9, 10, 11, 12, 13a-Lacaune (LC), 13b, 14- Slovak dairy sheep, 15- Improved Valachian (IV), 16- crossbreed IV/LC

\section{IMPACT SCC ON MILK YIELD}

Research related to the relationship between SCC and milk yield in goat and sheep confirm decrease milk production with increase of SCC in milk. Such, subclinical mastitis is considered the most important cause of reduced milk yield (Leitner $\boldsymbol{e t}$ al., 2004c; Raynal-Ljutovac et al., 2007; Leitner et al., 2008; Koop et al., 2010; Le Maréchal et al., 2011). Decline milk yield was from 3 to $10 \%$ in depending on species of pathogen and unilateral or bilateral infection (El- Saied et al., 1999; Gonzalo et al., 1994; Gonzalo et al., 2002). Gonzalo et al. (2002) showed that the highest milk yield was by healthy ewes, followed by ewes infected with minor pathogens and the lowest milk yield was found in ewes infected with major pathogens. Othomane $\boldsymbol{e t}$ al. (2002) observed a decrease in milk production in relation to the increase SCC in milk of Churra breed. Nudda et al. (2003) showed decreased milk yield of Sarda ewes with SCC over $1000 \times 10^{3}$ cells $/ \mathrm{ml}$ compared with ewes with SCC below $1000 \times 10^{3}$ cells $/ \mathrm{ml}$ (1015 and $1104 \mathrm{~g} / \mathrm{d}$, respectively). Throughout subclinical mastitis the milk yield of the infected halves was significantly lower than milk yield of the uninfected ones ( 0.36 and 0.76 kg/milking) (Leitner et al., 2004c). Silanikove et al. (2005) also documented decreased milk yield due to subclinical mastitis. According to Leitner et al. (2008), decline milk yield due to subclinical mastitis can reach $12.2 \%$ in herd with $75 \%$ incidence of intramammary infection. Ewes characterized during lactation by the number of somatic cells in milk from both udder halves up to $250 \times 10^{3}$ cells $/ \mathrm{m}$ produced more milk $(1092.44 \mathrm{ml})$ than ewes in which SCC in milk from one or both udder halves exceeded $250 \times 10^{3}$ cells $/ \mathrm{ml}(918.83$ and $762.34 \mathrm{ml})(P<0.01)$. Milk yield of ewes where SCC from both udder halves exceeded $250 \times 10^{3}$ cells $/ \mathrm{ml}$ was significantly lower than for ewes which SCC from one halves exceeded $250 \times$ $10^{3}$ cells $/ \mathrm{ml}(\mathrm{P}<0.01)$ (Olechnowicz et al., 2009). Olechnowicz et al. (2009) showed that SCC had a significant effect on daily milk production, established that if SCC from one or two half udder is over $250 \times 10^{3}$ cells $/ \mathrm{ml}$ milk yield decreased by $15.89 \%$ and $30.22 \%$ respectively. According to Cuccuru et al. (2011) in subclinical mastitis increase SCC and decrease milk yield of up to $25 \%$, while decline milk yield is more pronounced in staphylococcal infections than in intramammary streptococcal infections. Arias et al. (2012) showed that ewes with SCC below $300 \times 10^{3}$ cells $/ \mathrm{ml}$ had higher milk yield in compare with ewes with SCC over $300 \times 10^{3}$ cells $/ \mathrm{ml}(1199 \pm 641 \mathrm{ml} / \mathrm{d}$ and $1073 \pm 615 \mathrm{ml} / \mathrm{d})$. The estimated losses in milk yield according levels of SCC were approximately 16\% (Sutera et al., 2018).

In our breeding practise Margetín et al. (1996) found out that higher SCC was related to lower milk yield in Tsigai and Improved Valachian ewes. Vršková $\boldsymbol{e t}$ al. (2015a, 2015b) and Tančin et al. (2017a, table 2) observed a decrease in milk production in sheep with high SCC in milk, which was also confirmed in our latest study (Oravcová et al., 2018, table 3). Thus taking into account both abroad and our results we could conclude that though SCC is still do not considered as parameter for evaluation of milk quality in dairy ewes on milk trade, one has to point out that SCC should be considered in management of dairy farms if they want to produce milk more efficiently.

\section{IMPACT SCC ON MILK COMPOSITION}

Higher SCC, as mentioned above, has negative impact not only on milk production but the milk composition is affected as well which has negative influence on milk processing. One of the most important milk component is protein. Sheep milk with a high SCC contains more total protein than milk with low SCC (Nudda et al., 2003; Albenzio et al., 2004; Bianchi et al., 2004). Albenzio et al. (2004) investigated the percentages of protein in Comisana ewes in two groups with different SCC, in ewes with high SCC over $1000 \times 10^{3}$ cells $/ \mathrm{ml}$ a higher percentage of total protein was recorded in early and late lactation $(5.86$ and $6.27 \%)$ than in ewes from group with low SCC below $500 \times 10^{3}$ cells $/ \mathrm{ml}(5.40$ and $5.99 \%)$. During mastitis Albenzio et al. (2004) and Nudda et al. (2003) observed an increase in the concentration of soluble whey proteins as serumalbumin, immunoglobulins. Leitner et al. (2004c) detected in their study that the concentrations of total whey proteins and albumin were significantly higher in the infected than in the uninfected halves and concentrations of casein was significantly lower in the infected halves. Le Maréchal et al. (2011) reported in review an increase in the concentration of protein as result of the inflammatory and immune response and a decrease in endogenous milk protein such as casein throughout intramammary infection. Decrease of casein content was observed in infected Sarda dairy sheep compared to healthy ewes and also was found significantly higher content of tota protein in infected sheep (Bianchi et al., 2004). Silanikove et al. (2006) detected a decrease content of casein during subclinical mastitis. Martí De Olives et al. (2013) found out decrease of casein content during subclinical mastitis and throughout the postinfection period also. Content of protein was higher in milk samples with high somatic cell count $(5.48 \mathrm{~g} / 100 \mathrm{ml})$ in compared with content of protein and fat in milk samples with low somatic cell count $(5.23 \mathrm{~g} / 100 \mathrm{ml})$ (Paschino et al., 2019).

Lactose is another important component of milk representing the source of energy and osmotic regulation of milk volume in udder (Shamay et al., 2000). Reducing content of lactose in milk could indicate some problems in udder like mastitis (Leitner et al., 2003b). Analysis of milk sample for ewes of Sarda breed with low $\left(<500 \times 10^{3}\right.$ cells $\left./ \mathrm{ml}\right)$, middle $\left(500-1000 \times 10^{3}\right.$ cells $\left./ \mathrm{ml}\right)$ and high $\left(1000-2000 \times 10^{3}\right.$ cells/ml) SCC showed significantly more lactose $(4.74 \mathrm{~g} / 100 \mathrm{~g}$ milk) in milk with a low SCC than in milk from the other two groups, 4.54 and $4.38 \mathrm{~g} / 100 \mathrm{~g}$ milk, respectively $(P<0.01)$ (Pirisi $\boldsymbol{e t}$ al., 2000). Decrease in lactose content (from 4.55 to $4.14 \%$ ) with higher SCC reported Nudda et al. (2001) for Sarda ewes in their study. Nudda et al. (2003) found out decrease in concentration of lactose in sheep milk with increase SCC. The lactose content in milk from group with high SCC in early, middle and late lactation was significantly lower (4.47, 4.08 and $3.70 \%$, respectively) than in milk of ewes from group with low SCC (4.81, 4.59 and 4.36\%) ( $P<0.05)$ (Albenzio et al., 2004). Bianchi et al. (2004) found out a decrease of lactose content in infected Sarda dairy sheep compared to healthy ewes. Leitner et al. (2004c) detected in their study that concentrations of lactose were significantly lower in the infected halves. During subclinical mastitis a decrease content of lactose was observed (Silanikove et al., 2006). VivarQuintana et al. (2006) observed in Assaf $\times$ Churra and Castelana crossbred ewes 
a significant decrease of lactose content with higher SCC $(P<0.05)$. Olechnowicz et al. (2010) showed that SCC in milk below and above $250 \times 10^{3}$ cells $/ \mathrm{ml}$ had a significant effect on content of lactose. Also Martí De Olives et al. (2013) found in their study decrease of lactose content due to subclinical mastitis and this decrease remained throughout the postinfection period. Paschino et al. (2019) observed reduction of lactose content in milk with high somatic cell count in compared with content of lactose in milk with low somatic cell count (4.66 and $4.87 \mathrm{~g} / 100 \mathrm{ml}$, resp.).

Results concerning fat content are unclear even (Raynal- Ljutovac et al., 2007)

Leitner et al. (2003b) detected lower fat percentage in uninfected than in infected halves of udder $(4.68 \pm 0.08$ and $5.29 \pm 0.14$, resp.). Fat content in milk decreased significantly in infected udder halves (Bianchi et al., 2004). Vivar-Quintana $\boldsymbol{e}$ al. (2006) found out in Assaf $\times$ Churra and Castelana crossbred ewes that SCC did not significantly affect fat content of milk. Increase content of fat in milk with SCC over $250 \times 10^{3}$ cells $/ \mathrm{ml}$ in one and both half of udder was observed in study by Olechnowicz et al. (2010). Milk samples with high somatic cell count had higher content of fat $(6.54 \mathrm{~g} / 100 \mathrm{ml})$ in compared with content of fat in milk samples with low somatic cell count (6.28 g/100 ml) (Paschino et al., 2019).
Despite of increase content of fat and protein, yield of cheese decreases because the individual fractions in fat and protein are change and the content of casein decreases (Leitner $\boldsymbol{e t}$ al., 2004a; Caboni $\boldsymbol{e t}$ al., 2017). The fatty acids profile in milk with high SCC had also been altered (Caboni et al., 2017).

Under our conditions we have also studied relationship between SCC and milk composition. Margetín et al. (1996) found statistically significant relation between higher SCC and lower content of lactose $(P<0.001)$. Higher content of fat and protein were detected in milk samples of ewes with higher SCC (Margetín et al., 1996). Vršková et al. (2015a) determined that with increase SCC in milk, increased content of protein (from 6.17 to $6.61 \%$ ) and fat (from 7.20 to $8.04 \%$ ), while content of lactose decreased (from 4.78 to $4.32 \%$ ). The decrease of content of lactose were observed in study of Vršková et al. (2015b). Also the reduced content of lactose in relation to high SCC was also reported Tančin $\boldsymbol{e t}$ al. (2017a, table 2). Baranovič et al. (2018) recorded lower lactose content in milk samples with increase SCC (from 5.19 to $5.00 \%$ in May and from 4.88 to $4.72 \%$ in July). Oravcová et al. (2018) reported decrease in lactose content and increase fat and protein content with increasing SCC as show table 3.

Table 2 The effect of SCC groups on milk yield and milk composition (Tančin et al., 2017a) SCC groups

\begin{tabular}{|c|c|c|c|c|c|c|c|c|c|c|c|}
\hline & \multicolumn{2}{|c|}{ Low } & \multicolumn{2}{|c|}{ Middle } & \multicolumn{2}{|c|}{ Higher } & \multicolumn{2}{|c|}{ High } & \multicolumn{2}{|c|}{ Mastitis } & \\
\hline Variable & LSM & SE & LSM & SE & LSM & SE & LSM & SE & LSM & SE & $\mathrm{P}$ \\
\hline Milk yield, mL & $503^{a}$ & 6.61 & $450^{\mathrm{bc}}$ & 12.33 & $455^{\mathrm{bc}}$ & 17.43 & $465^{\mathrm{ab}}$ & 19.45 & $419^{c}$ & 13.22 & $<0.0001$ \\
\hline Fat, \% & $6.32^{\mathrm{a}}$ & 0.058 & $6.29^{\mathrm{a}}$ & 0.093 & $5.95^{\mathrm{b}}$ & 0.123 & $6.18^{\mathrm{ab}}$ & 0.137 & $6.23^{\mathrm{a}}$ & 0.099 & 0.0298 \\
\hline Protein, \% & $5.6^{\mathrm{a}}$ & 0.028 & $5.61^{\mathrm{a}}$ & 0.045 & $5.44^{\mathrm{b}}$ & 0.06 & $5.56^{\mathrm{ab}}$ & 0.066 & $5.68^{a}$ & 0.048 & 0.0117 \\
\hline Lactose, \% & $4.88^{\mathrm{a}}$ & 0.015 & $4.84^{\mathrm{ab}}$ & 0.024 & $4.76^{\mathrm{c}}$ & 0.032 & $4.78^{\mathrm{bc}}$ & 0.036 & $4.58^{\mathrm{d}}$ & 0.026 & $<0.0001$ \\
\hline
\end{tabular}

a-d within row significantly different at $\mathrm{P}<0.05$

Table 3 Least squares means and standard errors for milk traits by somatic cell count (SCC) class (Oravcová et al., 2018)

\begin{tabular}{|c|c|c|c|c|}
\hline \multicolumn{4}{|c|}{ SCC groups } & \multirow{3}{*}{ Scheffe's test } \\
\hline & Low & Middle & High & \\
\hline Trait & $\mathrm{N}=1763$ & $\mathrm{~N}=285$ & $\mathrm{~N}=575$ & \\
\hline Milk yield (ml) & $526.8 \pm 9.9$ & $503.8 \pm 12.4$ & $486.8 \pm 11.6$ & $1: 2^{+,} 3^{++}$ \\
\hline Fat content $(\%)$ & $6.91 \pm 0.05$ & $6.93 \pm 0.07$ & $7.08 \pm 0.07$ & $1: 3^{+} ; 2: 3^{+}$ \\
\hline Protein content $(\%)$ & $5.52 \pm 0.03$ & $5.58 \pm 0.03$ & $5.66 \pm 0.03$ & $1: 2^{+}, 3^{++} ; 2: 3^{+}$ \\
\hline Lactose content (\%) & $4.54 \pm 0.01$ & $4.50 \pm 0.02$ & $4.41 \pm 0.02$ & $1: 2,3^{++} ; 2: 3^{++}$ \\
\hline
\end{tabular}

SCC class: low - SCC under $300 \times 10^{3}$ cells/ ml, middle - SCC between $300 \times 10^{3}$ and $600 \times 10^{3}$ cells $/ \mathrm{ml}$, high - SCC above $600 \times 10^{3}$

cells $/ \mathrm{ml} ; \mathrm{N}$ - number of observations; ${ }^{*}-$ milk yield per milking; ${ }^{++}-\mathrm{P} \leq 0.01,+-\mathrm{P} \leq 0.05$

\section{COMPOSITION OF SOMATIC CELLS DEPENDING ON THE PRESENCE OF THE PATHOGEN}

SCC in milk increases during mastitis mainly as a result of increased migration of leukocytes from blood to mammary tissue (Leitner et al., 2003a; Le Roux et al. 2003). The analysis of the representation of individual types of leukocytes in milk can reveal changes in their numbers, which can provide information about inflammatory processes in the mammary gland (Pilla et al., 2012) with possible implementation for mastitis diagnostic in dairy practice (Damm et al., 2017) However, this research is mainly realised in dairy cows. One study analysed the effect of species (cow, goats and ewes), where the cellular immune response to CNS infection was similar for the three animal species, although the number of cells was different (Leitner et al., 2012).

In milk samples of cows with the highest SCC were dominant types of leukocytes polymorphonuclear leukocytes (PMNL): neutrophils, basophils and eosinophils, followed by macrophages and lymphocytes (Lindmark-Mansson et al., 2006) The increase PMNL in milk samples of cows was caused by infections with pathogens causing mastitis (Leitner et al., 2000). Albenzio and Caroprese (2011) detected that PMNL represented the main population of leukocyte in ewe's milk with high SCC (over $1000 \times 10^{3}$ cells/ml). PMNL being the principal leukocytes that increase during pathogen invasion and they may be considered a good marker to evaluate udder health (Albenzio and Caroprese, 2011). In dairy ewes the milk samples with $\mathrm{SCC}>1000 \times 10^{3}$ cells $/ \mathrm{ml}$ showed differences in leukocyte populations between uninfected and infected ewes, with higher percentages of PMNL and macrophages and lower percentages of lymphocytes in infected animals (Albenzio et al., 2012). Albenzio et al. (2012) showed that nonviable PMNL levels were the highest in ewe milk samples with SCC below $300 \times 10^{3}$ cells $/ \mathrm{ml}$, in contrast from SCC over $500 \times 10^{3}$ cells $/ \mathrm{ml}$ nonviable PMNL were higher in uninfected ewes than in infected ewes. Leitner et al. (2003a) reported that as chronic infection progressed the number of PMNL decreased and number of macrophages and lymphocytes increased. In the goat milk there was found out the changes of leucocyte population as a consequence of udder infection (Bagnicka et al., 2011). In another study the effect of mastitis even more affected neutrophils in goat milk where in noncontaminated milk neutrophils constitute 45 $74 \%$ of the total SCC, while in milk from infected separate mammary halves increased to 71-86\% (Paape $\boldsymbol{e t}$ al., 2007). Similar results published Boulaaba $\boldsymbol{e}$ al. (2011). Blagitz et al. (2011) in their study with goat's milk showed a significan positive correlation between the percentage of the viable neutrophils and milk SCC
( $\mathrm{r}=0.495, P=0.008$ ). Della Libera et al. (2011) found out that with higher California mastitis test (CMT) score which were in relation with higher SCC, they observed more neutrophils and less macrophages but lymphocytes count was without change. Pilla et al. (2012) used changes in the leukocyte ratio in milk to identify inflammatory processes in cows with low SCC to distinguish healthy quarters from those quarters that had an early and late inflammation, respectively. Takano et al. (2018) observed increase in neutrophil percentages in the udder from which mastitis causing pathogens were isolated.

Bagnicka et al. (2011) in their study observed that the percentage of neutrophils in noncontaminated samples constituted $15 \%$ in the total SCC. In milk samples with high numbers of minor and major pathogens, the neutrophils amounted to 21 and $32 \%$, respectively. Bagnicka et al. (2011) observed the effect of pathogens where they established increased neutrophils and eosinophils in milk samples from goats containing major pathogens such as $S$. aureus, $S$. intermedius, Str. agalactiae and an increased number of monocytes in samples of high occurrence mino pathogens such as CNS, Enterococcus sp., Corynebacterium sp. The type of pathogen didn't have effect on percentage of lymphocytes in total SCC (Bagnicka et al., 2011). Bagnicka et al. (2011) was shown that not only the neutrophils and monocytes, but also the eosinophils play a crucial defensive role against the pathogenic bacteria. Researches confirm the correlation between intramammary infection and the immune response of the organism in relation to different numbers of individual leukocyte types depending on the type of pathogen.

\section{IMPACT OF NON-INFECTIOUS FACTORS ON SCC IN MILK}

Breed, number of lambs, order and stage of lactation, age, oestrus, livestock management, the impact of the day, the month, the season are factors which can affect the SCC in the milk of ewes and goat (Gonzalo et al., 1994, 2002, 2005; Pappe et al., 2001, 2007; Olechnowicz et al., 2010; Arias et al., 2012; Souza et al., 2012). However, non-infectious factors can cause changes in SCC of sheep milk from $40 \times 10^{3}$ to $100 \times 10^{3}$ cells $/ \mathrm{ml}$ Bergonier et al. (2003) and Gonzalo et al. (2002).

Milk composition in Comisana ewes was affected by the stage of lactation and lambing season (Sevi et al., 2004). Sevi et al. (2004) observed that irrespective of the lambing season, a higher SCC was recorded in late-lactation, compared to early- and mid-lactation (6.16 vs. 5.93 and $5.87 \log _{10}$ somatic cells $\left./ \mathrm{ml}\right)$. The stage of lactation was statistically significant effect on SCC $(P<0.01)$ (Olechnowicz $\boldsymbol{e}$ al., 2010). Bonelli et al. (2013) found no significant differences between sampling 
from early till late stage of lactation although SCC trend seemed to increased. Romero et al. (2017) found out that the highest level SCC were in samples taken at $2^{\text {nd }}$ week from lambing $\left(276 \times 10^{3}\right.$ cells $\left./ \mathrm{ml}\right)$, level SCC gradually decreased, and the lowest SCC was reached at $12^{\text {th }}$ week from lambing $\left(95 \times 10^{3}\right.$ cells $\left./ \mathrm{ml}\right)$. In our recent study the effect of stage of lactation on SCC was not significant (Oravcová et al., 2018) though there were tendency of changes throughout of lactation
(Tančin et al., 2017b, Table 4). Also the frequency of distribution of milk samples into different SCC groups was not clearly influenced by stage of lactation (Idris et al., 2015). Such results could contribute to the evidence that animals should be healthy during whole lactation.

Table 4 The effect of stage of lactation on milk yield, milk composition and SCC (Tančin et al., 2017b)

\begin{tabular}{|c|c|c|c|c|c|}
\hline & \multicolumn{5}{|c|}{ Milk composition $(\%)$} \\
\hline Stage of lactation & Milk yield (ml) & Fat & Protein & Lactose & $\mathrm{SCC}(\mathrm{cell} / \mathrm{ml})$ \\
\hline 30-60. days & $962.09^{a} \pm 49.33$ & $5.28^{\mathrm{a}} \pm 0.18$ & $5.25^{\mathrm{a}} \pm 0.09$ & $4.87^{\mathrm{a}} \pm 0.04$ & $5.51 \pm 0.10$ \\
\hline 60-90. days & $1038.39^{\mathrm{a}} \pm 21.2$ & $5.12^{\mathrm{a}} \pm 0.08$ & $5.44^{\mathrm{a}} \pm 0.04$ & $4.78^{\mathrm{ac}} \pm 0.02$ & $5.54 \pm 0.04$ \\
\hline 90-120. days & $844.82^{b} \pm 27.53$ & $5.81^{\mathrm{c}} \pm 0.11$ & $5.72^{b} \pm 0.05$ & $4.69^{b c} \pm 0.02$ & $5.47 \pm 0.05$ \\
\hline 120-150. days & $637.08^{\mathrm{d}} \pm 31.34$ & $6.52^{\mathrm{d}} \pm 0.12$ & $6.00^{c} \pm 0.06$ & $4.57^{\mathrm{d}} \pm 0.03$ & $5.44 \pm 0.06$ \\
\hline 150-180. days & $524.37^{c} \pm 23.63$ & $7.35^{\mathrm{b}} \pm 0.09$ & $6.59^{\mathrm{d}} \pm 0.04$ & $4.43^{\mathrm{ef}} \pm 0.02$ & $5.46 \pm 0.05$ \\
\hline 180-210. days & $460.41^{\mathrm{cd}} \pm 42.29$ & $6.83^{\text {bd }} \pm 0.16$ & $6.60^{\mathrm{d}} \pm 0.08$ & $4.49^{\mathrm{df}} \pm 0.04$ & $5.56 \pm 0.08$ \\
\hline $210<$. days & $378.36^{\mathrm{d}} \pm 54.98$ & $7.3^{\mathrm{bd}} \pm 0.21$ & $6.63^{\mathrm{d}} \pm 0.10$ & $4.27^{\mathrm{e}} \pm 0.05$ & $5.66 \pm 0.11$ \\
\hline
\end{tabular}

Note: $^{\mathrm{a}, \mathrm{b}, \mathrm{c}, \mathrm{d}, \mathrm{e}, \mathrm{f}} \mathrm{LS}$ means in the same column with different letters are different $(P<0.05)$.

Arias et al. (2012) found out that ewes with twins and more lambs had higher SCC in compare with ewes with one lamb. In milk of ewes with two and three lambs were higher SCC than in milk of ewes with one lamb $\left(1659 \times 10^{3}: 708 \times 10^{3}\right.$ cells/ml, respect.) (Prpic et al., 2016). This fact could be due to probably related to greater mechanic damage during lambing two and more lambs.

Moroni et al. (2007) observed that SCC had upward trend as parity increased. Olechnowicz et al. (2010) showed a significant effect of parity of ewes on SCC $\left(\log\right.$ SCC) from udder halves below $250 \times 10^{3}$ cells $/ \mathrm{ml}$. The youngest ewes had the lowest SCC, while the oldest ewes showed in general the highest SCC and the lowest milk yield (Arias et al., 2012). Subclinical mastitis occurred less frequently in primiparous ewes than those with two or more lactations significantly $(P<0.05)$ and ewes in third lactation had the most cases of subclinical mastitis (Sani et al.,
2015). Takano et al. (2018) showed in their study that multiparous Lacaune ewes had a higher incidence of intramammary infections during early lactation than primiparous ewes. The increase of SCC in multiparous ewes could be attributed to potential intramammary infection in previous lactating period.

The breeds could also affect SCC in milk. The most samples over $1000 \times 10^{3}$ cells $/ \mathrm{ml}$ had ewes of Lacaune compared to ewes of Tsigai, Improved Valachian $\times$ Lacaune and Slovak dairy sheep (Tančin et al., 2017a, Oravcová et al., 2018 (tables 5 and 6). Farms with Friesarta breed had the highest prevalence of subclinical mastitis and the smallest prevalence of subclinical mastitis was recorded in farms with Assaf breed (Vasileiou et al., 2018b).

Table 5 Frequency of distribution of SCC in milk samples from different breeds and their crossbreds (Idriss et al., 2015)

\begin{tabular}{lcccccc}
\hline \multirow{2}{*}{ Breeds } & \multirow{2}{*}{$\mathbf{N}$} & \multicolumn{5}{c}{ SCC groups (\%) } \\
\cline { 3 - 7 } & & $\mathrm{G}_{1}$ & $\mathrm{G}_{2}$ & $\mathrm{G}_{3}$ & $\mathrm{G}_{4}$ & $\mathrm{G}_{5}$ \\
\hline TS & 211 & 47.39 & 29.38 & 9.00 & 5.21 & 9.00 \\
TS $\times$ LC & 814 & 41.03 & 23.10 & 12.41 & 6.63 & 16.83 \\
$\mathbf{L C}$ & 577 & 38.82 & 27.4 & 11.61 & 6.7 & 16.46 \\
$\mathbf{I V}$ & 54 & 66.67 & 24.7 & 5.56 & 3.70 & 0.00 \\
$\mathbf{I V} \times \mathbf{L C}$ & 976 & 38.63 & 28.38 & 9.73 & 7.7 & 16.19
\end{tabular}

SCC- Somatic cell count, TS- Tsigai, LC- Lacaune, IV- Improved Valachian, TS $\times$ LCcrossbreeds, IV $\times$ LC- crossbreeds. G1 $=$ Group 1 of $\left(\mathrm{SCC}<100 \times 10^{3}\right.$ cells $\left./ \mathrm{ml}\right), \mathrm{G} 2=(\mathrm{SCC}$ between $100-300 \times 10^{3}$ cells $\left./ \mathrm{ml}\right), \mathrm{G} 3=\left(\mathrm{SCC}\right.$ between $300-600 \times 10^{3}$ cells $/ \mathrm{ml}, \mathrm{G} 4=(\mathrm{SCC}$ between $600-1000$

$\times 10^{3}$ cells $\left./ \mathrm{ml}\right)$ and $\mathrm{G} 5=\left(\mathrm{SCC}>1000 \times 10^{3}\right.$ cells $\left./ \mathrm{ml}\right), \mathrm{N}=$ The number of ewes.

Table 6 Least squares means and standard errors for milk traits and decadic logarithm of somatic cell count (log $\left.{ }_{10} \mathrm{SCC}\right)$ by genotype (Oravcová et al., 2018)

\begin{tabular}{|c|c|c|c|c|c|c|}
\hline \multirow{3}{*}{ Trait } & \multicolumn{5}{|l|}{ Genotype } & \multirow{3}{*}{ Scheffe's test } \\
\hline & TS (1) & IV (2) & LC (3) & $\mathrm{TS} \times \mathrm{LC}(4)$ & $\mathrm{IV} \times \mathrm{LC}(5)$ & \\
\hline & $\mathrm{N}=194$ & $\mathrm{~N}=49$ & $\mathrm{~N}=577$ & $\mathrm{~N}=826$ & $\mathrm{~N}=977$ & \\
\hline Milk yield, ml & $374.9 \pm 21.0$ & $438.7 \pm 36.4$ & $625.3 \pm 12.3$ & $516.9 \pm 11.0$ & $573.2 \pm 10.5$ & $1: 3,4,5^{++}, 2: 3,5^{++}, 3: 4^{++}, 4.5^{++}$ \\
\hline Fat content, \% & $6.93 \pm 0.11$ & $6.89 \pm 0.20$ & $6.87 \pm 0.07$ & $7.17 \pm 0.06$ & $7.02 \pm 0.06$ & $3: 4^{++}$ \\
\hline Protein content, $\%$ & $5.56 \pm 0.06$ & $5.81 \pm 0.10$ & $5.43 \pm 0.03$ & $5.69 \pm 0.03$ & $5.44 \pm 0.03$ & $1: 4^{+}, 2: 3,5^{+}, 4: 5^{++}$ \\
\hline Lactose content, \% & $4.46 \pm 0.03$ & $4.45 \pm 0.05$ & $4.54 \pm 0.02$ & $4.48 \pm 0.01$ & $4.49 \pm 0.01$ & $3: 4^{+}$ \\
\hline $\log _{10} \mathrm{SCC} / \mathrm{ml}$ & $5.20 \pm 0.07$ & $4.71 \pm 0.13$ & $5.34 \pm 0.04$ & $5.31 \pm 0.04$ & $5.33 \pm 0.04$ & $1: 2^{+}, 2: 3,4,5^{++}$ \\
\hline
\end{tabular}

Season and temperatures during year could impact to SCC and occurrence of bacteria in udder of ewes. Ewes had the lowest SCC and highest milk yield in spring and highest SCC and lowest milk yield had in winter (Arias et al., 2012). January, February and March had a significantly higher risk of being infected by mastitis pathogens than April and May (Kern et al., 2013). During the winter months due to the higher transpiration and respiration of ewes in stables could higher damp stimulates bacterial growth. This higher microbial pressure could affect the higher SCC during the winter season.

The management of dairy ewes at farm levels is a critical factor that should be taking into account if SCC is evaluated. Sevi et al. (2003) mentioned that in intensively managed herds, where surface area smaller than $7 \mathrm{~m}^{2}$ per ewe was available, there was an increased risk of clinical mastitis. Ewes allowed access to the outdoor area had lower SCC in their milk, whereas reduced space allowance led to an increase in SCC of milk (Caroprese et al., 2009). The SCS (somatic cell score) was significantly lower in extensive (3.00) compared to dairy (4.41) and meat systems (4.72) (Kern et al., 2013). Vasileiou et al. (2018a) detected prevalence of subclinical mastitis more frequently in farms managed semiintensively $(0.296)$ or intensively $(0.254)$ and less frequently in farms managed semi-extensively $(0.196)$ or extensively $(0.178)$. We observed in our study significantly impact farm management on SCC (Tvarožková et al., 2019).
Romero et al. (2017) in their study found out, that SCC were higher in milk from evening milking $\left(162 \times 10^{3}\right.$ cells $\left./ \mathrm{ml}\right)$ than morning milking $\left(129 \times 10^{3}\right.$ cells $\left./ \mathrm{ml}\right)$. Despite these non-infectious factors, intramammary infection is the main cause that leads to increase SCC in sheep milk (Leitner et al. 2001; Pappe et al., 2001; 2007; Raynal- Ljutovac et al., 2007; Souza et al., 2012). Thus non-infectious factors contribute only to the tendency of increasing or decreasing of SCC within possible physiological range and they could explain some risk factors determining the mastitis occurrence.

\section{CONCLUSIONS}

On the basis of available results from the world laboratory the physiological levels of SCC for diagnosis of subclinical mastitis of udder of dairy ewes significantly reduced during last years but this question is still open. Our results and obtained experiences coming from the frequency of distribution of milk samples among SCC groups could indicate that most of the samples were in SCC group below 400 $\times 10^{3}$ cells $/ \mathrm{ml}$. Also we showed that the most of the milk samples obtained from half udder with high SCC were connected with the presence of microorganisms indicating the subclinical mastitis. Thus SCC in milk give reliable information about udder health and therefore low SCC indicate good udder health. Also the 
management (effect of farms) play important role as it was presented by different SCC among farms with the same breed of ewes. On the other side breeds with high yield were more affected by subclinical mastitis. Obtained results under Slovakian conditions also show how important regular milk recording including SCC analysis is for further improvement of udder health because there was demonstrated clear negative effect of high SCC on milk yield and its composition under practical conditions. Though there is negligible using antibiotics id mastitis treatment in Slovakian sheep farms the mentioned results about antibiotic resistance showed in some antibiotics difficulties in their using in dairy practice. Taking into account presented information in our review there is the high needs to extend the number of sheep farms involved in regular milk recording which increase the available data for farmers to manage their farms more effectively with emphasis on milk performance efficiency where udder health play crucial role.

Acknowledgements: Supported by the Ministry of Education Science Research and Sports of the Slovak Republic/the Slovak Research and Development Agency (Project No. APVV-15-0072).

\section{REFERENCES}

ADDIS, M.F.- TEDDE, V.- DORE, S.- PISANU, S.- PUGGIONI, G. M.ROGGIO, A. M.- PAGNOZZI, D.- LOLLAI, S.- CANNAS, E. A.- UZZAU, S. 2016. Evaluation of milk cathelicidin for detection of dairy sheep mastitis. Journal of Dairy Science, 99(8), 6446-6456. http://dx.doi.org/10.3168/jds.2015-10293 ALBENZIO, M.- CAROPRESE, M. 2011. Differential leucocyte count for ewe milk with low and high somatic cell count. Journal of Dairy Research, 78(1), 4348.https://doi.org/10.1017/S0022029910000798

ALBENZIO, M.- CAROPRESE, M.- SANTILLO, A.- MARINO R.- TAILI, L. SEVI, A. 2004. Effect of somatic cell count and stage of lactation on the plasmin activity and cheese-making properties of ewe milk. Journal of Dairy Science, 87(3), 533-542. https://doi.org/10.3168/jds.S0022-0302(04)73194-X

ALBENZIO, M.- SANTILlO, A.- CAROPRESE, M.- RUGGIERI, D. CILIBERTI, M.- SEVI, A. 2012. Immune competence of the mammary gland as affected by somatic cell and pathogenic bacteria in ewes with subclinical mastitis Journal of Dairy Science, 95(7), 3877-3887. http://dx.doi.org/ 10.3168/jds.20125357

ALBENZIO, M.- TAIBI, L.- MUSCIO, A.- SEVI, A. 2002. Prevalence and etiology of subclinical mastitis in intensively managed flocks and related changes in the yield and quality of ewe milk. Small Ruminant Research, 43(3), 219-226 https://doi.org/10.1016/S0921-4488(02)00022-6

ARIAS, R.- OLIETE, B- RAMÓN, M.- ARIAS, C.- GALLEGO, R.- MONTORO, V.- GONZALO, C.- PÉREZ-GUZMÁN, M. D. 2012. Long-term study od environmental effects on test- day somatic cell count and milk yield in Manchega sheep. Small Ruminant Research, 106(2-3), 92-97. http://dx.doi.org/10.1016/j.smallrumres.2012.03.019

ARIZNABARRETA, A.- GONZALO, C.- SAN PRIMITIVO, F. 2002 Microbiological Quality and Somatic Cell Count of Ewe Milk with Specia Reference to Staphylococci. Journal Dairy Science, 85(6), 1370-1375. https://doi.org/10.3168/jds.S0022-0302(02)74203-3

ATTILI, A. R.- PREZIUSO, S.- NGU NGWA, V.- CANTALAMESSA, A.MORICONI, M.- CUTERI, V. 2016. Clinical evaluation of the use of enrofloxacin against Staphylococcus aureus clinical mastitis in sheep. Small Ruminant Research, 136, 72-77. http://dx.doi.org/10.1016/j.smallrumres.2016.01.004

BAGNICKA, E.- WINNICKA, A.- JOZWIK, A.- RZEWUSKA, M.STRZALKOWSKA, N.- KOŚCIUCZUK, E.- PRUSAK, B.- KABA, B.HORBAŃCZUK, J.- KRZYZEWSKI, J. 2011. Relationship between somatic cell count and bacterial pathogens in goat milk. Small Ruminant Research, 100(1), 7277. https://doi.org/10.1016/j.smallrumres.2011.04.014

BALABÁNOVÁ, M.- FILIPČÍK, R.- HASOŇOVÁ, L.- HORKÝ, P.- HOŠEK M.- KONEČNÝ, R.- PAVLATA, L.- VANDASOVÁ, P.- VESELÝ, P. 2014 Nové poznatky voblasti mastitid přežvýkavců. 1. vyd. Brno: Mendelova univerzita, 90 p. ISBN 978-80-7509-178-9.

BARANOVIČ, Š. 2017. [Udder health of lactating cows and ewes and its relationship to lameness]: PhD. dissertation. Nitra: SPU. $135 \mathrm{p}$.

BARANOVIČ, Š.- TANČIN, V.- TVAROŽKOVÁ, K.- UHRINČAT, M.MAČUHOVÁ, L.- PALKOVIČ, J. 2018. Impact of somatic cell count and lameness on the production and composition of ewe's milk. Potravinarstvo Slovak Journal of Food Sciences, 12(1), 116-121. https://doi.org/10.5219/900

BERGONIER, D.- BERTHELOT, X. 2003. New advances in epizootiology and control of ewe mastitis. Livestock Production Science, 79(1), 1-16. https://doi.org/10.1016/S0301-6226(02)00145-8

BERGONIER, D.- DE CRÉMOUX, R.- RUPP, R.- LAGRIFFOUL, G. BERTHELOT, X. 2003. Mastitis of dairy small ruminants. Veterinary Research, 34(5), 689-716. https://dx.doi.org/10.1051/vetres:2003030

BERTHELOT, X.- LAGRIFFOUL, G.- CONCORDET, D.- BARILLET, FBERGONIER, D. 2006. Physiological and pathological thresholds of somatic cell counts in ewe milk. Small Ruminant Research, 62(1-2), 27-31. https://doi.org/10.1016/j.smallrumres.2005.07.047
BIANCHI, L.- BOLLA, A.- BUDELLI, E.- CAROLI, A.- CASOLI, C. PAUSELLI, M.- DURANTI, E. 2004. Effect of udder health status and lactation phase on the characteristics of Sardinian ewe milk. Journal of Dairy Science, 87(8), 2401-2408. https://doi.org/10.3168/jds.S0022-0302(04)73362-7

BLAGITZ, M. G.- SOUZA, F. N.- BATISTA, C. F.- DINIZ, S. A.- HADDAD, J. P. A.- BENITES, N. R.- MELVILLE, M. A.- DELLA LIBERA, A. M. M. P. 2014 Clinical findings related to intrammamary infections in meat- producing ewes Tropical Animal Health and Production, 46(1), 127-132. https://doi.org/10.1007/s11250-013-0462-8

BLAGITZ, M. G.- SOUZA, F. N., GOMES, V., DELLA LIBERA, A. M. M. P. 2011. Apoptosis and necrosis of polymorphonuclear leukocytes in goat milk with high and low somatic cell counts. Small Ruminant Research, 100(1), 67-71. https://doi.org/10.1016/j.smallrumres.2011.05.005

BOETTCHER, P. J.- MORONI, P.- PISONI, G.- GIANOLA, D. 2005. Application of a finite mixture model to somatic cell scores of Italian goats. Journal Dairy Science, 88(6), 2209-2216. https://doi.org/10.3168/jds.S0022-0302(05)72896-4 BONELLI, P.- DIMAURO, C.- RE, R.- PILO, G.- DORE, S.- CANNAS, A. E. NICOLUSSI, P. S. 2013. Peripheral blood and milk leukocytes subsets of lactating Sarda ewes. Italian Journal of Animal Science, 12(2), 208-212. https://doi.org/10.4081/ijas.2013.e34

BOULAABA, A.- GRABOWSKI, N.- KLEIN, G. 2011. Differential cell count of caprine milk by flow cytometry and microscopy. Small Ruminant Research, 97(13), 117-123. https://doi.org/10.1016/j.smallrumres.2011.02.002

BRAMIS, G.- GELASAKIS, A. I. KIOSSIS, E.- BANOS, G.- ARSENOS, G. 2016. Predisposing factors and control of bacterial mastitis in dairy ewes. Journal of the Hellenic Veterinary Medical Society, 67(4), 211-222. http://dx.doi.org/10.12681/ihvms.15641

CABONI, P.- MANIS, C.- IBBA, I.- CONTU, M.- CORONEO,V.- SCANO, P 2017. Compositional profile of ovine milk with a high somatic cell count: A metabolomics approach. International Dairy Journal, 69, 33-39. https://doi.org/10.1016/j.idairyj.2017.02.001

CAROPRESE, M.- ANNICCHIARICO, G.- SCHENA, L.- MUSCIO, A.MIGLIORE, R.- SEVI, A. 2009. Influence od space allowance and housing conditions on the welfare, immune response and production performance of dairy ewes. Journal of Dairy Research, 76(1), 66-73. https://doi.org/10.1017/S0022029908003683

CLEMENTS, A. C. A.- TAYLOR, D. J.- FITZPATRICK, D. J.- 2003. Evaluation of diagnostic procedures for subclinical mastitis in meat-producing sheep. Journal of Dairy Research, 70(2), 139-148. https://doi.org/10.1017/S0022029903006022 CONTRERAS, G. A.- RODRIGUEZ, J. M. 2011. Mastitis: Comparative Etiology and Epidemiology. Journal of Mammary Gland Biology and Neoplasia, 16(4), 339-356. https://doi.org/10.1007/s10911-011-9234-0

CONTRERAS, A.- SIERRA, D.- SÁNCHEZ, Z. A.- CORRALES, J. C MARCO, J.C- PAAPE, M. J- GONZALO, C. 2007. Mastitis in small ruminants Small Ruminant Research, 68(1-2), 145-153. https://doi.org/10.1016/j.smallrumres.2006.09.011

CORRENTE, M.- GRECO, G.- MADIO, A.- VENTRIGLIA, G. 2003. Methicillin resistance in staphylococci isolated from subclinical mastitis in sheep. The New Microbiologica, 26(1), 39-45

CUCCURU, C.- MELONI, M.- SALA, E.- SCACCABAROZZI, L.- LOCATELI, C.- MORONI, P.- BRONZO, V. 2011. Effects of intramammary infections on somatic cell score and yield in Sarda sheep. New Zealand Veterinary Journal, 59(3), 128-131. https://doi.org /10.1080/00480169.2011.562862

DAMM, M.- HOLM, C.- BLAABJERG, M.- NOVAK BRO, M.- SCHWARZ, D 2017. Differential somatic cell count-A novel method for routine mastitis screening in the frame of Dairy Herd Improvement testing programs. Journal of Dairy Science, 100(6), 4926-4940. https://doi.org/10.3168/jds.2016-12409

DELLA LIBERA, A. M. M. - BLAGITZ, M. G.- SOUZA, F. N.- BATISTA, C F.- AZEDO, M. R.- GOMES, V. 2011. Somatic Cell and Differential Leukocytes Count in Relation to California Mastitis Test in Santa Ines Ewes' Milk. Indian Veterinary Journal, 88(9), 19-21.

DORE, S.- LICIARDI, M.- AMATISTE, S.- BERGAGNA, S.- BOLZONI, G.CALIGIURI, V.- CERRONE, A.- FARINA, G.- MONTAGNA, C. O.- SALETTI M. A.- SCATASSA, M. L.- SOTGIU, G.- CANNAS, E. A. 2016. Survey on small ruminant bacterial mastitis in Italy, 2013-2014. Small Ruminant Research, 141, 9193. https://doi.org/10.1016/j.smallrumres.2016.07.010

EL-SAIED, U. M.- CARRIEDO, J. A.- DE LA FUENTE, L. F.- SAN PRIMITIVO, F. 1999. Genetic parameters of lactation cell counts and milk and protein yield in dairy ewes. In Journal Dairy Science, 82(3), 639-644. https://doi.org/10.3168/jds.S0022-0302(99)75278-1

ERGÜN, Y.- ASLANTAS, O.- DOGRUER, G.- KIRECCI, E.- SARIBAY, M. K. ATES, C. T.- ULKU, A.- DEMIR, C. 2009. Prevalence and etiology of subclinical mastitis in Awasi dairy ewes in southern Turkey. Turkish Journal of Veterinary \& Animal Science, 33(6), 477-483.

GELASAKIS, A.I.- MAVROGIANNI, V. S.- PETRIDIS, I. G.- VASILEIOU, N G. C.- FTHENAKIS, G. C. 2015. Mastitis in sheep - The last 10 years and future of research. Veterinary Microbiology, 181(1-2), 136-146. http://dx.doi.org/doi:10.1016/j.vetmic.2015.07.009 
GIADINIS, N. D.- ARSENOS, G.- TSAKOS, P.- PSYCHAS, V.- DOVAS, C. I.PAPADOPOULOS, E.- KARATZIAS, H.- FTHENAKIS, G. C. 2012. "Milk- drop syndrome of ewes": Investigation of the causes in dairy sheep in Greece. Small Ruminant Research, 106(1)

$33-35$ https://doi.org/10.1016/j.smallrumres.2012.04.018

GONZALO, C.- ARIZNABARRETA, A.- CARRIEDO, J. A.- SAN PRIMITIVO, F. 2002. Mammary Pathogens and their relationship to somatic cell count and milk yield losses in dairy ewes. Journal Dairy Science, 85(6), 1460-1467. https://doi.org/10.3168/jds.S0022-0302(02)74214-8

GONZALO, C.- CARRIEDO, J. A.- BLANCO, M. A.- BENEITEZ, E.- JUÁREZ, M. T.- DE LA FUENTE, L. F.- SAN PRIMITIVO, F. 2005. Factors of variation influencing bulk tank somatic cell count in dairy sheep. Journal Dairy Science, 88(3), 969-974. https://doi.org/10.3168/jds.S0022-0302(05)72764-8

GONZALO, C.- CARRIEDO, J. A.- GOMEZ, J. D.- SAN PRIMITIVO, F. 1994 Diurnal variation in the somatic cell count of ewe milk. Journal Dairy Science, 77(7), 1856-1859.

GONZALO, C. - GAUDIOSO LACASA, V. R. 1985. Evolution des types cellulaires du laits de bredis (race Churra) en fonction des dénombrements cellulaires totaux pendant latraite mécanique et manuelle. Annales de Zootechnie, 34(3), 257-264.

GONZÁLES-RODRÍGEZ, M. C.- GONZALO, C.- SAN PRIMITIVO, F.- C. 1995. Relationship between somatic cell count and intramammary infection of the half udder in dairy ewes. Journal Dairy Science, 78(12), 2753-2759. https://doi.org/10.3168/jds.S0022-0302(95)76906-5

GUARANÁ, E. L. S.- SANTOS, R. A.- CAMPOS, A. G. S. S.- SILVA, N. S.AFONSO, J. A. B.- MENDONCA, C. L. 2011. Cellular Dynamics and microbiological of milk of Santa Inês ewes accompanied during lactation $\begin{array}{llll}\text { Pesquisa Veterinária } & \text { Brasileira, } & 31(10), & 851-858 .\end{array}$ http://dx.doi.org/10.1590/S0100-736X2011001000004

HALL, S. M.- RYCROFT, A. N. 2007. Causative organisms and somatic cell counts in subclinical intramammary infections in milking goats in the UK. Veterinary Record, 160(1), 19-22. http://dx.doi.org/10.1136/vr.160.1.19

HARIHARAN, H.- DONACHIE, W.- MACALDOWIE, C.- KEEFE, G. 2004 Bacteriology and somatic cell counts in milk samples from ewes on a Scottish farm. Canadian Journal of Veterinary Research, 68(3), 188-192.

HOLKO, I.- TANČIN, V.- TVAROŽKOVÁ, K.- SUPUKA, P.- SUPUKOVÁ, A 2018. Udder Pathogens Isolated from Sheep Milk in Slovakia. XLVIII. Lenfeldovy a Höklovy dny. Brno: Veterinární a farmaceutická univerzita, 169-172. ISBN 97880-7305-808-1.

HOLKO, I.- TANČIN, V.- TVAROŽKOVÁ, K.- SUPUKA, P.- SUPUKOVÁ, A. MAČUHOVÁ, L. 2019. Occurence and antimicrobial resistance of common udder pathogens isolated from sheep milk in Slovakia. Potravinarstvo Slovak Journal of Food Sciences, 13(1), 258-261. https://doi.org/10.5219/1067

HUSSEIN, H. A.- EL-KHABAZ, K. A. S.- MALEK, S. S. 2015. Is udder ultrasonography a diagnostic tool for subclinical mastitis in sheep? Small Ruminan Research, 129, 121-128. https://doi.org/10.1016/j.smallrumres.2015.05.010

IDRISS, S. E.- TANČIN, V.- MARGETÍN, M.- TANČINOVÁ, D.- SLÁMA, P. HAVLÍČEK, Z. 2015. Frequency of distribution of somatic cell count in dairy ewe's milk. Journal of Microbiology, Biotechnology and Food Sciences, 4(3), 148 151. https://doi.org/10.15414/jmbfs.2015.4.special3.148-151

KERN, G.- TRAULSEN, I.- KEMPER, N.- KRIETER, J. 2013. Analysis of somatic cell counts and risk factors associated with occurrence of bacteria in ewe of different primary purposes. Livestock Science, 157(2-3), 597-604 https://doi.org/10.1016/j.livsci.2013.09.008

KIOSSIS E.- BROZOS C. N.- PETRIDOU E.- BOSCOS C.2007. Program for the control of subclinical mastitis in dairy Chios breed ewes during lactation. Small Ruminant Research, 73(1), 194-199. https://doi.org/10.1016/j.smallirumres.2007.01.021

KOOP, G.- RIETMAN, J. F.- PIETERSE, M. C. 2010. Staphylococcus aureus mastitis in Texel sheep associated with suckling twins. Veterinary Record, 164(22), 868-869, ISBN 0042-4900. http://dx.doi.org/10.1136/vr.c3375

KUNZ, F.- CORTI, S.- GIEZENDANNER, N.- STEPHAN, R.- WITTENBRINK, M. M.- ZWEIFEL, C. 2011. Antimicrobial resistance of Staphylococcus aureus and coagulase- negative staphylococci isolated from mastitis milk samples from sheep and goats. Schweizer Archiv fur Tierheilkunde, 153(2), 63-69. https://doi.org/10.1024/0036-7281/a000152

LEITNER, G.- ELIGULASHVILY, R.- KRIFUCKS, O.- PERL, S.- SARAN, A. 2003a. Immune cell differentiation in mammary gland tissues and milk of cows chronically infected with Staphylococcus aureus. Journal of Veterinary Medicine $B$ Infectious Diseases and Veterinary Public Health, 50(1), 45-52. https://doi.org/10.1046/j.1439-0450.2003.00602.x

LEITNER, G.- CHAFFER, M.- CARASO, Y.- EZRA, E.- KABABEA D. WINKLER, M.- GLICKMAN, A.- SARAN, A. 2003b. Udder infection and milk somatic cell count, NAGase activity and milk composition- fat, protein and lactosein Israeli-Assaf and Awasi sheep. Small Ruminant Research, 49(2), 157-164. https://dx.doi.org/10.1016/S0921-4488(03)00079-8

LEITNER, G.- CHAFFER, M.- KRIFUCKS, O.- GLICKMAN, A.- EZRA, FSARAN, A. 2000. Milk leukocyte populations in heifers free of udder infection.
Journal of Veterinary Medicine, 47(2), 133-138. https://doi.org/10.1046/j.14390450.2000.00329.x

LEITNER, G.- CHAFFER, M.- SHAMAY, A.- SHAPIRO, F.- MERIN, U.- EZRA, E.-SARAN, A.- SILANIKOVE, N. 2004c. Changes in milk composition as affected by subclinical mastitis in sheep. Journal of Dairy Science, 87(1), 46-52. https://doi.org/10.3168/jds.S0022-0302(04)73140-9

LEITNER, G.- CHAFFER, M.- ZAMIR, S.- MOR, T.- GLICKMAN, A. WINKLER, M.- WEISBLIT, L.- SARAN, A. 2001. Udder disease etiology, milk somatic cell counts and NAGase activity in Israeli Assaf sheep throughout lactation. Small Ruminant Research, 39(2), 107-112. https://dx.doi.org/10.1016/S0921-4488(00)00190-5

LEITNER, G.- MERIN, U.- GLICKMAN, A.- WEISBLIT, L.- KRIFUCKS, O.SHWIMMER, A.- SARAN, A. 2004a. Factors influencing milk quantity and quality in Assaf sheep and goat crossbreds. South African Journal of Animal Science, 34 (Suppl. 1)(5), 162-164.

LEITNER, G.- MERIN, U.- KRIFUCKS, O.- BLUM, S.- RIVAS, A. L.SILANIKOVE, N. 2012. Effects of intra-mammary bacterial infection with coagulase negative staphylococci and stage of lactation on shedding of epithelial cells and infiltration of leukocytes into milk: Comparison among cows, goats and sheep. Veterinary Immunology and Immunopathology, 147(3-4), 202-210. https://doi.org/10.1016/j.vetimm.2012.04.019

LEITNER, G.- MERIN, U.- SILANIKOVE, N. 2004b. Changes in milk composition as affected by subclinical mastitis in goats. Journal of Dairy Science, 87(6), 1719-1726. https://doi.org/10.3168/jds.S0022-0302(04)73325-1

LEITNER, G.- SILANIKOVE, N.- MERIN, U. 2008. Estimate of milk and curd yield loss of sheep and goats with intrammamary infection and its relation to somatic cell count. Small Ruminant Research, 74(1-3), 221-225. http://dx.doi.org/10.1016/j.smallrumres.2007.02.009

LE MARÉCHAL, C.- THIÉRY, R.- VAUTOR, E.- LE LOIR, Y. 2011. Mastitis impact on technological properties of milk and quality of milk products - a review. Dairy Science \& Technology, 91(3), 247-282. https://doi.org/10.1007/s13594011-0009-6

LE ROUX, Y.- LAURENT, F.- MOUSSAOUI, F. 2003. Polymorphonuclear proteolytic activity and milk composition change. Veterinary Research, 34(5), 629-645. https://doi.org/10.1051/vetres:2003021

LINDMARK-MANSSON, H.- BRÄNING, G.- ALDÉN, G.- PAULSSON, M. 2006. Relationship between somatic cell count, individual leukocyte populations and milk compositions in bovine udder quarter milk. International Dairy Journal, 16(7), 717-727. https://doi.org/10.1016/j.idairyj.2005.07.003

LOLLAI, S. A.- ZICCHEDDU, M.- DI MAURO, C.- MANUNTA, D.- NUDDA, A.- LEORI, G. 2008. Profile and evolution of antimicrobial resistance of ovine mastitis pathogens (1995-2004). In Small Ruminant Research, 74, 1-3, p. 249-254. https://doi.org/10.1016/j.smallrumres.2007.04.007

MAČUHOVÁ, L.- TANČIN, V.- MAČUHOVÁ, J.- UHRINČAT, M. HASOŇOVÁ, L.- MARGETÍNOVÁ, J. 2017. Effect of Ewes Entry Order into Milking Parlour on Milkability and Milk Composition. Czech Journal Animal Science, 62(9), 392-402. https://doi.org/10.17221/11/2016-CJAS

MARGETIN, M.- ČAPISTRÁK, A.- ŠPÁNIK, J.- FOLTYS, V.1996. Somatic cells in sheep milk in relation to milkproduction and composition during sucking and milking. Živočišna výroba, 41(12), 543-550.

MARGETIN, M.-ČAPISTRÁK, A.- VALKOVSKY, P.- ŠPÁNIK, J.- FOLTYS, V. 1995. Variation in somatic-cell counts inewes milk during lactation. Živočišñ výroba, 40(6), 257-261.

MARGETÍN, M.- MILERKSI, M.- APOLEN, D.- ČAPISTRÁK, A. ORAVCOVÁ, M.- DEBRECÉNI, O. 2013. Relationships between production quality of milk and udder health status of ewes during machine milking. Journal of Central European Agriculture, 14(1), 328-340. https://doi.org/10.5513/JCEA01/14.1.1203

MARGETÍN, M.- ORAVCOVÁ, M.- HUBA, J.- JANÍČEK, M. 2017 Formationand characterization of Slovak dairy composite sheep breed: Description of the process: A Review. Slovak Journal Animal Science, 50(4), 139-143.

MAROGNA, G.- ROLESU, S.- LOLLAI, S.- TOLA, S.- LEORI, G. 2010. Clinical findings in sheep farms affected by recurrent bacterial mastitis. Small Ruminant Research, 88(2-3), 119-125. https://doi.org/10.1016/j.smallrumres.2009.12.019

MARTINS, K B.- FACCIOLI, P. Y.- BONESSO, M. F.- FERNANDES, S. OLIVEIRA, A. A.- DANTAS, A.- ZAFALON, L. F.- CUNHA, M. L. R. S. 2017. Characteristics of resistance and virulence factors in different species of coagulasenegative staphylococci isolated from milk of healthy sheep and animals with subclinical mastitis. Journal of Dairy Science, 100(3), 2184-2195. https://doi.org/10.3168/ids.2016-11583

MARTÍ DE OLIVES, A. M.- DÍAZ, J. R.- MOLINA, M. P.- PERIS, C 2013. Quantification of milk yield and composition changes as affected by subclinical mastitis during the current lactation in sheep. Journal of Dairy Science, 96(12), 7698-7708. http://dx.doi.org/ 10.3168/jds.2013-6998

MASÁR, M., 1968. [A study on various methods of labour organization at the first experimental machine-milking of sheep in Czechoslovakia.] Vedecké práce Výskumného ústavu ovčiarskeho v Trenčíne, 4: 75-87.

MAURER, J.- SCHAEREN, W. 2007. Udder health and somatic cell count in ewes. Agrarforschung, 14, 162-167. 
MAVROGIANNI, V. S.- GRIPPS, P. J.- FTHENAKIS, G. C. 2007. Bacterial flora and risk of infection of the ovine teat duct and mammary gland throughout lactation. Preventive Veterinary Medicine, 79(2-4), 163-173. https://doi.org/10.1016/j.prevetmed.2006.11.014

MAVROGIANNI, V. S.- MENZIES, P. I.- FRAGKOU, I. A.- FTHENAKIS, G. C. 2011. Principles of mastitis treatment in sheep and goats. Veterinary Clinics of North America: Food Animal Practice, 27(1), 115-120. https://doi.org/10.1016/j.cvfa.2010.10.010

MCDOUGALL, S.- PANKEY, W.- DELANEY, C.- BARLOW, J.MURDOUGH, P. A.- SCRUTON, D. 2002. Prevalence and incidence of subclinical mastitis in goats and dairy ewes in Vermont, USA. Small Ruminant Research, 46(2), 115-121. https://doi.org/10.1016/S0921-4488(02)00191-8

MIKUŠ, M. 1973. [Milk ejection during machine milking of sheep during lactation period]. Živočišna výroba, 18, 469-475.

MILERSKI, M. - MARGETÍN, M. - ČAPISTRÁK, A. - APOLEN, D. - ŠPÁNIK, J. - ORAVCOVÁ, M. 2006. Relationships between external udder measurementsand the linear scores for udder morphology traits in dairy sheep. Czech Journal of Animal Science, 51(9), 383-390. https://doi.org/10.17221/3955CJAS

MØRK, T.- WAAGE, S.- TOLLERSRUD, T.- KVITLE, B.- SVILAND, S. 2007. Clinical mastitis in ewes; bacteriology, epidemiology and clinical features. Acto Veterinaria Scandinavica, 49, 23-30. https://doi.org/10.1186/1751-0147-49-23

MORONI, P. CUCCURU, P. 2001. Relationship between mammary gland infections and some milk immune parameters in Sardinian breed ewes. Small Ruminant Research, 41(1), 1-7. https://doi.org/10.1016/S0921-4488(01)00193-6 MORONI, P.- PISONI, G.- RUFFO, G.- BOETTCHER, P. J. 2005a. Risk factors for intramammary infections and relationship with somatic-cell counts in Italian dairy goats. Preventive Veterinary Medicine, 69(3-4), 163-173. 10.1016/j.prevetmed.2004.10.013

MORONI, P.- PISONI, G.- RUFFO, G.- CORTINOVIS, I.- CASAZZA, G. 2005b. Study of intramammary infections in dairy goats from mountainous in Italy. New Zealand Veterinary Journal, 53(5), 375-376. https://doi.org/10.1080/00480169.2005.36580

MORONI, P.- PISONI, G.- VARISCO, G.- BOETTCHER, P. 2007. Effect of intramammary infection in Bergamasca meat sheep on milk parameters and lamb growth. Journal of Dairy Research, 74(3), 340-344. https://doi.org/10.1017/S0022029907002506

NUDDA, A.- FELIGINI, M.- BATTACONE, G.- NICOLÒ PIETRO PAOLO MACCIOTTA, N. P. P.- PULINA, G. 2003. Effects of lactation stage, parity, $\beta$ lactoglobulin genotype and milk SCC on whey protein composition in Sarda dairy ewes. Italian Journal of Animal Science, 2(1), 29-39. https://doi.org/10.4081/ijas.2003.29

NUDDA A.- FELIGINI M.- MURGIA P.- PULINA G. 2001. Relationship between somatic cells count, whey protein and coagulation properties in sheep milk. Proceedings of 14th National ASPA Congress, Firenze, 511-513.

NUNES, G. R.- BLAGITZ, M. G.- FREITAS C. F.- SOUZA, F .N.- RICCIARDI, M.- STRICAGNOLO, C. R.- SANCHES, B. G. S.- AZEDO, M. R.- SUCUPIRA, M. C. A.- DELLA LIBERA, A. M. M. P. 2008. Evaluation of the indicators of inflammation in the diagnosis of ovine mastitis. Arquivos do Instituto Biológico, $75,271-281$

OLECHNOWICZ, J.- JASKOWSKI, J. M. 2005. Somatic cells in sheep milk. Medycyna Weterynaryjna, 61(2), 136-141.

OLECHNOWICZ, J.- JASKOWSKI, J. M. 2014. Mastitis in small ruminants. Medycyna Weterynaryjna, 70(2), 67-72.

OLECHNOWICZ, J.- JAŚKOWSKI, J. M.- ANTOSIK, P.- BUKOWSKA, D. 2009. Milk yield and composition in line 05 dairy ewes as related to somatic cell counts. Journal of Animal and Feed Sciences, 18(3), 420-428. https://doi.org/10.22358/jafs/66417/2009

OLECHNOWICZ, J.- SOBEK, Z.- JAŚKOWSKI, J.M.- ANTOSIK, P. BUKOWSKA, D. 2010. Connection of somatic cells count and milk yield as well as composition an dairy ewes. Archiv Tierzucht, 53(1), 95-100, ISBN 0003-9438. https://doi.org/10.5194/aab-53-95-2010

OMALEKI, L.- BARBER, S. R.- ALLEN, J. L.- BROWNING, G. F. 2010 Mannheimia species associated with ovine mastitis. Journal of Clinical Microbiology, 48(9), 3419-3422. https://doi.org/10.1128/JCM.01145-10

ONNI, T.- SANNA, G.- LARSEN, J.- TOLA, S. 2011. Antimicrobial susceptibilities and population structure of Staphylococcus epidermidis associated with ovine mastitis. Veterinary Microbiology, 148(1), 45-50. https://doi.org/10.1016/j.vetmic.2010.07.024

ORAVCOVÁ, M.- MAČUHOVÁ, L.- TANČIN, V. 2018. The relationship between somatic cells and milk traits, and their variation in dairy sheep breeds in Slovakia. Journal of Animal and Feed Sciences, 27(2), 97-104. https://doi.org/10.22358/jafs/90015/2018

ORAVCOVÁ, M.- MARGETÍN, M.- TANČIN, V. 2015. The effect of stage of lactation on daily milk yield and milk fat and protein content in Tsigai and Improved Valachian ewes. Mljekarstvo, 65(1), 48-56. https://doi.org/10.22358/jafs/90015/2018

OTHOMANE, M. H.- CARRIEDO, J. A.- DE LA FUENTE, L. F.- SAN PRIMITIVO, F. 2002. Factors affecting test-day milk composition in dairy ewes and relationships amongst various milk components. Journal Dairy Science, 69(1) 53-62. https://doi.org/10.1017/S0022029901005234

OZENC, E.- SEKER, E.- BAKI ACAR, D.- BIRDANE, M. K.- DARBAZ, I.DOGAN, N. 2011. The importance of staphylococci and threshold value of somatic cell count for diagnosis of subclinical mastitis in Pirlak sheep at midlactation. Reproduction in Domestic Animals, 46(6), 970974. https://doi.org/10.1111/j.1439-0531.2011.01768.x

PAAPE, M. J.- POUTREL, B.- CONTRERAS, A.- MARCO, J. C.- CAPUCO, A. V. 2001. Milk Somatic Cells and Lactation in Small Ruminants. Journal of Dairy Science, 84, Supplement, E237-E244. https://doi.org/10.3168/jds.S0022 0302(01)70223-8

PAAPE, M. J.- WIGGANS, G. R.- BANNERMAN, D. D.- THOMAS, D. L.SANDERS, A. H.- CONTRERAS, A.- MORONI, P.- MILLER, R. H. 2007. Monitoring goat and sheep milk somatic cell counts. Small Ruminant Research, 68(1-2), 114-125. https://doi.org/10.1016/j.smallrumres.2006.09.014

PASCHINO, P.- VACCA, G. M.- DETTORI, M. L.- PAZZOLA M. 2019. An approach for estimation of somatic cells' effect in Sarda sheep milk based on analysis of milk traits and coagulation properties. Small Ruminant Research, 171, 77-81. https://doi.org/10.1016/j.smallirumres.2018.10.010

PENGOV, A. 2001. The Role of Coagulase- Negative Staphylococcus sp. and Associated Somatic Cell Counts in the Ovine Mammary Gland. Journal of Dairy Science, 84(3), 572-574. https://doi.org/10.3168/jds.S0022-0302(01)74509-2

PERSSON, Y.- NYMAN, A. K.- SÖDERQUIST, L.- TOMIC, N.- PERSSON WALLER, K. 2017. Intramammary infections and somatic cell count in meat and pelt producing ewes with clinically healthy udders. Small Ruminant Research, 156, 66-72. http://dx.doi.org/10.1016/j.smallrumres.2017.09.012

PILIPČINCOVÁ, I.- BHIDE, M.- DUDRIKOVÁ, E.- TRÁVNIČEK, M. 2010. Genotypic Characterization of Coagulase- negative Staphylococci Isolated from Sheep Milk in Slovakia. Acta Veterinaria Brno, 79(2), 269-275. https://doi.org/10.2754/avb201079020269

PILLA, R.- SCHWARZ, D.- KÖNIG, S.- PICCININI, R. 2012. Microscopic differential cell counting to identify inflammatory reactions in dairy cow quarter milk samples. Journal of Dairy Science, 95(8), 4410-4420. http://dx.doi.org/ 10.3168/jds.2012-5331

PIRISI A.- PIREDDA G.- CORNA M.- PES M.- PINTUS S.- LEDDA A. 2000. Influence of somatic cell count on ewe's milk composition, cheese yield and cheese quality. Proceedings of 6th Great Lakes Dairy Sheep Symposium. Guelph, Canada, 47-59.

PRPIC, Z.- VNUČEC, I.- BENIĆ, M.- MIOČ , B. 2016. Relationship of litter size with yield, udder morphology and udder health of East Friesian sheep. Journal of Central European Agriculture, 17(4), 1331-1345. https://doi.org/10.5513/JCEA01/17.4.1853

QUEIROGA, M. C. 2017. Prevalence and aetiology of sheep mastitis in Alentejo regions of Portugal. Small Ruminant Research, 153, 123-130 http://dx.doi.org/10.1016/j.smallrumres.2017.06.003

QUEIROGA, M. C.- DUARTE, E. L.- LARANJO, M. 2018. Sheep mastitis Staphylococcus epidermidis biofilm effects on cell adhesion and inflamatory change. Small Ruminant Research, 168, 6-11. https://doi.org/10.1016/j.smallrumres.2018.09.009

QUINN, P. J.- MARKEY, B. K.- LEONARD, F. C.- FITZPATRICK, E. S. FANNING, S.- HARTIGAN, P. J. 2011. Veterinary Microbiology and Microbial Disease, 2nd ed. West Sussex: Wiley-Blackwell, 837-850, ISBN 978-1-40515823-7.

RAHMAN, B.- OWNAGH, A.- MARDANI, K.- ARDEBIL, F. F. 2016 Prevalence and molecular characterization of staphylococci isolated from sheep with subclinical mastitis in West-Azerbaijan province, Iran. Veterinary Research Forum, 7(2), 155-162

RAYNAL-LJUTOVAC, K.- PIRISI, A.- DE CRÉMOUX, R.- GONZALO, C. 2007. Somatic cells of goat and sheep milk: Analytical sanitary, productive and technological aspects. Small Ruminant Research, 68(1-2), 126-144.

RIGGIO, V.- PORTOLANO, B. 2015. Genetic selection for reduced somatic cell counts in sheep milk: A review. Small Ruminant Research, 126(10), 33-42. https://doi.org/10.1016/j.smallrumres.2006.09.012

ROMERO, G.- ROCA, A.- ALEJANDRO, M.- MUELAS, R.- DÍAZ, J. R. 2017 Relationship of mammary gland health status and other noninfectious factors with electrical conductivity of milk in Manchega ewes. Journal of Dairy Science, 100(2), 1555-1567. https://doi.org/10.3168/jds.2016-11544

SANI, R. N.- MAHDAVI, A.- MOEZIFAR, M. 2015. Prevalence and etiology of subclinical mastitis in dairy ewes in two seasons in Semman province, Iran. Tropical Animal Health and Production, 47(7), 1249-1254. https://doi.org/10.1007/s11250-015-0855-y

SANTANA, R. C. M.- ZAFALON, L. F.- ESTEVES, S. N.- TANAKA, E. V.PILON, L. E.- MASSA, R. 2013. Occurrence of etiologic agents causing subclinical mastitis in Morada Nova and Santa Ines ewes. ARS Veterinaria, Jaboticabal, 29(3), 148-152. http://dx.doi.org/10.15361/21750106.2013v29n3p148-152

SEVI, A.- ALBENZIO, M.- MARINO, R.- SANTILLO, A.- MUSCIO, A. 2004 Effects of lambing season and stage of lactation on ewe milk quality. Small 
Ruminant Research, 51(3), 251-259. https://doi.org/10.1016/S09214488(03)00196-2

SEVI, A.- ALBENZIO, M.- MUSCIO, A.- CASAMASSIMA, D.CENTODUCATI, P. 2003. Effects of litter management on airborne particulates in sheep houses and on the yield and quality of ewe milk. Livestock Production Science, 81, 1-9. https://doi.org/10.1016/S0301-6226(02)00228-2

SHAMAY, A.- SHAPIRO, F.- BARASH, H.- BRUCKENTAL, I.SILANIKOVE, N. 2000. Effect of dexamethasone on milk yield and composition in dairy cows. Annals de Zootechnie, 49(4), 343-352.

SILANIKOVE, N.- MERIN, U.- LEITNER, G. 2006. Physiological role of indigenous milk enzymes: An overview of an evolving picture. In International Dairy Journal, 16(6), 535-545. https://doi.org/10.1016/j.idairyj.2005.08.015

SILANIKOVE, N.- SHAPIRO, F.- LEITNER, G.- MERIN, U. 2005. Subclinical mastitis affects the plasmin system, milk composition and curd yield in sheep and goats: comparative aspects. In: Hogeveen, H. (Ed.), Mastitis in Dairy Production. Wageningen Academic Press Publishers, The Netherlands, 511-516.

SOUZA, F. N.- BLAGITZ, M. G.- PENNA, C. F. A. M.- DELLA LIBERA, A.M M. P.- HEINEMANN, M. B.- CERQUEIRA, M.M.O.P. 2012. Somatic cell count in small ruminants: Friend or foe? Small Ruminant Research, 107(2-3), 65-75. http://dx.doi.org/10.1016/j.smallrumres.2012.04.005

SPANU, C.- BERGER, Y. M.- THOMAS, D. L.- RUEGG, P. L. 2011. Impact of intramammary antimicrobial dry treatment and teat sanitation on somatic cell count and intamammary infection in ewes. Small Ruminant Research, 97(1-3), 139-145. https://doi.org/10.1016/j.smallrumres.2011.03.005

SPURIA, L.- BIASIBETTI, E.- BISANZIO, D.- BIASATO, I- DE MENEGHI, D.- NEBBIA, P.- ROBINO, P.- BIANCO, P.- LAMBERTI, M.- CARUSO, C.- DI BLASI, A.- PELETTO, S.- MASOERO, L.- DONDO, A.- CAPUCCHIO, M. T. 2017. Microbial agents in macroscopically healthy mammary gland tissues of small ruminants. PeerJ, 5(11). https://doi.org/10.7717/peerj.3994

SUTERA, A. M.- PORTOLANO, B - DI GERLANDO, R- SARDINA, M. T. MASTRANGELO, S.- TOLONE, M. 2018. Determination of milk production losses and variations of fat and protein percentages according to different levels of somatic cell count in Valle del Belice dairy sheep. Small Ruminant Research, 162, 39-42. https://doi.org/10.1016/j.smallrumres.2018.03.002

SWIDEREK, W. P.- CHARON, K. M.- WINNICKA, A.- GRUSZCZYNSKA, J.PIERZCHALA, M. 2016. Physiological Threshold of Somatic Cell Count in Milk of Polish Heath Sheep and Polish Lowland Sheep. Annals of Animal Science, 16(1), 155-170. https://doi.org/10.1515/aoas-2015-0071

TAKANO, P. V.- SCAPINI, V. A. D. C.- VALENTINI, T.- GIRARDINI, L. K.DE SOUZA, F. N.- DELLA LIBERA, A. M. M. P.- HEINEMANN, M. B.CHANDE, C. G.- CORTEZ, A.- COLLET, S. G.- DINIZ, S. A.- BLAGITZ, M G. 2018. Milk cellularity and intramammary infections in primiparous and multiparous Lacaune ewes during early lactation. Small Ruminant Research, 167, 117-122. https://doi.org/10.1016/j.smallrumres.2018.08.015

TANČIN, V.- BARANOVIČ, Š.- UHRINČAŤ, M.- MAČUHOVÁ, L. VRŠKOVÁ, M.- ORAVCOVÁ, M. 2017a. Somatic cell count in raw ewes milk in dairy practice: frequency of distribution and possible effect on milk yield and $\begin{array}{lll}\text { composition. } & \text { Mljekarstvo, 67(4), 253-260. }\end{array}$ https://doi.org/10.15567/mljekarstvo.2017.0402

TANČIN, V.- HOLKO, I.- VRŠKOVÁ, M.- UHRINČǍ̌, M.- MAČUHOVÁ, L. $2017 \mathrm{c}$. Relationship between presence of mastitis pathogens and somatic cell coun in milk of ewes. XLVII. Lenfeldovy a Höklovy dny. Brno: Veterinárni a farmaceutická univerzita, 230-233. ISBN 978-80-7305-793-0.

TANČIN, V.- UHRINČAT̆, M.- MAČUHOVÁ, L.- BARANOVIČ, Š. VRŠKOVÁ, M. 2017b. Somatic cell count in milk of individual Lacaune ewes under practical conditions in Slovakia: Possible effect on milk yield and its composition. Potravinarstvo Slovak Journal of Food Sciences, 11(1), 386-390. https://doi.org/10.5219/767

TVAROŽKOVÁ, K.- TANČIN, V.- UHRINČǍ̆, M.- MAČUHOVÁ, L.TOMAN, R.- TUNEGOVÁ, M. 2018. Evaluation of somatic cells in milk of ewes as possible physiological level. Acta Fytotechnica et Zootechnica, 21(4), 149-151. https://doi.org/10.15414/afz.2018.21.04.149-151

TVAROŽKOVÁ, K.- TANČIN, V.- UHRINČAŤ, M.- MAČUHOVÁ, L.TVAROŽKOVÁ, K.- TANČIN, V.- UHRINČAŤ, M.- MAČUHOVÁ, L.VRŠKOVÁ, M.- ORAVCOVÁ, M. 2019. Somatic cell count during first and second lactation in ewes. Potravinarstvo Slovak Journal of Food Sciences, 13(1), 396-401. https://doi.org/10.5219/1059

ÜNAL, N.- ASKAR, S.- MACUN, H. C.- SAKARYA, F.- ALTUN, B.YILDIRIM, M. 2012. Panton- Valentine leukocidin and some exotoxins of Staphylococcus aureus and antimicrobial susceptibility profiles of staphylococci isolated from milks of small ruminants. Tropical Animal Health and Production, 44(3), 573-579. https://doi.org/10.1007/s11250-011-9937-7

VASILEIOU, N. G. C.- CRIPPS, P. J.- IOANNIDI, K. S.- CHATZOPOULOS, D. C.- GOUGOULIS, D. A.- SARROU, S.- ORFANOU, D. C.- POLITIS, A. P.CALVO GONZALEZ-VALERIO, T.- ARGYROS, S.- MAVROGIANNI, V. S.PETINAKI, E.- FTHENAKIS, G. C. 2018a. Extensive countrywide field investigation of subclinical mastitis in sheep in Greece. Journal of Dairy Science, 101(8), 7297-7310. https://doi.org/10.3168/ids.2017-14075
VASILEIOU, N. G. C.- GOUGOULIS, D. A.- RIGGIO, V.- IOANNIDI, K. S.CHATZOPOULOS, D. C.- MAVROGIANNI, V. S.- PETINAKI, E.FTHENAKIS, G. C. 2018b. Association of subclinical mastitis prevalence with sheep breeds in Greece. Journal of Dairy Research, 85(3), 317-320. https://doi.org/10.1017/S0022029918000407

VASIL', M.- ELEČKO, J.- FARKAŠOVÁ, Z.- ZIGO, F. 2018. Development of resistance to antibiotics in bacteria Staphylococcus sp. Isolated from milk samples in the sheep breedings on east of Slovakia. Potravinarstvo Slovak Journal of Food Sciences, 12(1), 273-278. https://doi.org/10.5219/904

VASIL', M.- ELEČKO, J.- FARKAŠOVÁ, Z.- ZIGO, F.- LAPIN, M. 2016. Antibiotic Resistance in Bacteria Staphylococcus sp. Isolated From Samples of Raw Sheep's Milk. Potravinarstvo Slovak Journal of Food Sciences, 10(1), 619624

https://doi.org/10.5219/680

VIVAR-QUINTANA A.M.- BENEITEZ DE LA MANO E.- REVILLA I. 2006. Relationship between somatic cell counts and the properties of yoghurt made from ewes' milk. International Diary Journal, 16(3), 262-267. https://doi.org/10.1016/i.idairyj.2005.03.006

VRŠKOVÁ, V.- TANČIN, V.- KIRCHNEROVÁ, K.- SLÁMA, P. 2015a Evaluation of daily milk production in Tsigai ewes by somatic cell count. Potravinarstvo Slovak Journal of Food Sciences, 9(1), 206-210. https://doi.org/10.5219/439

VRŠKOVÁ, V.- TANČIN, V.- KIRCHNEROVÁ, K.- SLÁMA, P. 2015b. Impact of selected parameters on milk production in Tsigai breed. Journal of Microbiology, Biotechnology and Food Sciences, 4(3), 185-187. https://doi.org/10.15414/jmbfs.2015.4.special3.185-187

ZAFALON, L. F.- SANTANA, R. C. M.- ESTEVES, S. N.- JÚNIOR, G. A. F. 2018. Somatic cell count in the diagnosis of subclinical mastitis in sheep of different breeds. Semina: Ciencias Agrarias, 39(4), 1555-1564 http://dx.doi.org/10.5433/1679-0359.2018v39n4p1555

ZAFALON, L. F.- SANTANA, R. C. M.- PILON, L. E.- FIM JÚNIOR, G. A 2016. Diagnosis of subclinical mastitis in Santa Ines and Morada Nova sheep in southeastern Brazil. Tropical Animal Health and Production, 48, 697-972. https://doi.org/10.1007/s11250-016-1046-1

ZIGO, F.- VASIL, M.- ELEČKO, J.- FARKAŠOVÁ, Z.- LAPIN, M. 2014. Production of enterotoxins of Staphylococcus sp. isolated from samples of sheep milk. Potravinarstvo, 8(1), 92-96. https://doi.org/10.5219/361

ZIGO, F.- VASIL', M.- KADÁŠI, M.- ELEČKO, J.- FARKAŠOVÁ, Z. 2011. Bacteria Staphylococcus sp. izolated from mastitis of sheep and their enterotoxigenic properties. Potravinarstvo Slovak Journal of Food Sciences, 5(4), 70-72. https://doi.org/10.5219/171

ZIGO, F.- VASIL', M.- TAKÁČ, L.- ELEČKO, J.- TOMKO, J.- CHRIPKOVÁ, M. 2017. Mastitis pathogens isolated from samples of milk in dairy sheep and their resistance. International Journal of Scientific Research, 6(8), 298-300. 